University of Nebraska - Lincoln

DigitalCommons@University of Nebraska - Lincoln

Biological Systems Engineering: Papers and

Publications

Biological Systems Engineering

2008

\title{
Variability Analyses of Alfalfa-Reference to Grass-Reference Evapotranspiration Ratios in Growing and Dormant Seasons
}

\author{
Suat Irmak \\ University of Nebraska-Lincoln, suat.irmak@unl.edu \\ Ayse Kilic \\ University of Nebraska-Lincoln, akilic@unl.edu \\ T. A. Howell \\ USDA-ARS Conservation and Production Research Laboratory, Terry.Howell@ars.usda.gov \\ Derrel Martin \\ University of Nebraska-Lincoln, derrel.martin@unl.edu
}

J. O. Payero

Dept. of Primary Industries and Fisheries, jpayero@clemson.edu

See next page for additional authors

Follow this and additional works at: https://digitalcommons.unl.edu/biosysengfacpub

Part of the Biological Engineering Commons

Irmak, Suat; Kilic, Ayse; Howell, T. A.; Martin, Derrel; Payero, J. O.; and Copeland, K. S., "Variability Analyses of Alfalfa-Reference to Grass-Reference Evapotranspiration Ratios in Growing and Dormant Seasons" (2008). Biological Systems Engineering: Papers and Publications. 82.

https://digitalcommons.unl.edu/biosysengfacpub/82

This Article is brought to you for free and open access by the Biological Systems Engineering at DigitalCommons@University of Nebraska - Lincoln. It has been accepted for inclusion in Biological Systems Engineering: Papers and Publications by an authorized administrator of DigitalCommons@University of Nebraska Lincoln. 
Authors

Suat Irmak, Ayse Kilic, T. A. Howell, Derrel Martin, J. O. Payero, and K. S. Copeland 


\title{
Variability Analyses of Alfalfa-Reference to Grass-Reference Evapotranspiration Ratios in Growing and Dormant Seasons
}

\author{
S. Irmak, M.ASCE${ }^{1}$; A. Irmak, M.ASCE${ }^{2}$; T. A. Howell, M.ASCE${ }^{3}$; D. L. Martin, M.ASCE${ }^{4}$; \\ J. O. Payero, M.ASCE ${ }^{5}$; and K. S. Copeland ${ }^{6}$
}

\begin{abstract}
Alfalfa-reference evapotranspiration $\left(\mathrm{ET}_{r}\right)$ values sometimes need to be converted to grass-reference $\mathrm{ET}\left(\mathrm{ET}_{o}\right)$, or vice versa, to enable crop coefficients developed for one reference surface to be used with the other. However, guidelines to make these conversions are lacking. The objectives of this study were to: (1) develop $\mathrm{ET}_{r}$ to $\mathrm{ET}_{o}$ ratios $\left(K_{r}\right.$ values) for different climatic regions for the growing season and nongrowing (dormant) seasons; and (2) determine the seasonal behavior of $K_{r}$ values between the locations and in the same location for different seasons. Monthly average $K_{r}$ values from daily values were developed for Bushland, (Tex.), Clay Center, (Neb.), Davis, (Calif.), Gainesville, (Fla.), Phoenix (Ariz.), and Rockport, (Mo.) for the calendar year and for the growing season (MaySeptember). $\mathrm{ET}_{r}$ and $\mathrm{ET}_{o}$ values that were used to determine $K_{r}$ values were calculated by several methods. Methods included the standardized American Society of Civil Engineers Penman-Monteith (ASCE-PM), Food and Agriculture Organization Paper 56 (FAO56) equation (68), 1972 and 1982 Kimberly-Penman, 1963 Jensen-Haise, and the High Plains Regional Climate Center (HPRCC) Penman. The $K_{r}$ values determined by the same and different methods exhibited substantial variations among locations. For example, the $K_{r}$ values developed with the ASCE-PM method in July were 1.38, 1.27, 1.32, 1.11, 1.28, and 1.19, for Bushland, Clay Center, Davis, Gainesville, Phoenix, and Rockport, respectively. The variability in the $K_{r}$ values among locations justifies the need for developing local $K_{r}$ values because the values did not appear to be transferable among locations. In general, variations in $K_{r}$ values were less for the growing season than for the calendar year. Average standard deviation between years was maximum 0.13 for the calendar year and maximum 0.10 for the growing season. The ASCE-PM $K_{r}$ values had less variability among locations than those obtained with other methods. The FAO56 procedure $K_{r}$ values had higher variability among locations, especially for areas with low relative humidity and high wind speed. The 1972 Kim-Pen method resulted in the closest $K_{r}$ values compared with the ASCE-PM method at all locations. Some of the methods, including the ASCE-PM, produced potentially unrealistically high $K_{r}$ values (e.g., 1.78, 1.80) during the nongrowing season, which could be due to instabilities and uncertainties that exist when estimating $\mathrm{ET}_{r}$ and $\mathrm{ET}_{o}$ in dormant season since the hypothetical reference conditions are usually not met during this period in most locations. Because simultaneous and direct measurements of the $\mathrm{ET}_{r}$ and $\mathrm{ET}_{o}$ values rarely exist, it appears that the approach of $\mathrm{ET}_{r}$ to $\mathrm{ET}_{o}$ ratios calculated with the ASCE-PM method is currently the best approach available to derive $K_{r}$ values for locations where these measurements are not available. The $K_{r}$ values developed in this study can be useful for making conversions from $\mathrm{ET}_{r}$ to $\mathrm{ET}_{o}$, or vice versa, to enable using crop coefficients developed for one reference surface with the other to determine actual crop water use for locations, with similar climatic characteristics of this study, when locally measured $K_{r}$ values are not available.
\end{abstract}

DOI: 10.1061/(ASCE)0733-9437(2008)134:2(147)

CE Database subject headings: Evapotranspiration; Vegetation; Crops; Seasonal variations.

\section{Introduction}

Accurate crop water use estimates are essential for the development of modern irrigation management methodologies, optimum allocation of water and energy resources, and improved irrigation planning and management practices. Reference evapotranspiration $\left(\mathrm{ET}_{\text {ref }}\right)$ adjusted with the crop coefficient $\left(K_{c}\right)$ approach continues to be one of the most commonly used procedures for estimating crop water requirements $\left(\mathrm{ET}_{c}\right)$. This is a practical method because it provides a conservative means of estimating

\footnotetext{
${ }^{1}$ Assistant Professor, Dept. of Biological Systems Engineering, Univ. of Nebraska-Lincoln, 241 L.W. Chase Hall, Lincoln, NE 68583-0726 (corresponding author). E-mail: sirmak2@unl.edu

${ }^{2}$ Assistant Professor, School of Natural Resources and Dept. of Civil Engineering, Univ. of Nebraska-Lincoln, 311 Hardin Hall, Lincoln, NE 68583-0973.

${ }^{3}$ Supervisory Agricultural Engineer and Research Leader, USDA-ARS Conservation and Production Research Laboratory, P.O. Drawer 10, Bushland, TX 79012-0010.

${ }^{4}$ Professor, Dept. of Biological Systems Engineering, Univ. of Nebraska-Lincoln, 243 L.W. Chase Hall, Lincoln, NE 68583-0726.

${ }^{5}$ Senior Research Scientist, Dept. of Primary Industries and Fisheries, Irrigated Farming Systems, 203 Tor St., P.O. Box 102, Toowoomba, Qld
}

\section{0, Australia.}

${ }^{6}$ Soil Scientist, USDA-ARS Conservation and Production Research Laboratory, Water Management Research Unit, P.O. Drawer 10, Bushland, TX 79012-0010.

Note. Discussion open until September 1, 2008. Separate discussions must be submitted for individual papers. To extend the closing date by one month, a written request must be filed with the ASCE Managing Editor. The manuscript for this paper was submitted for review and possible publication on November 29, 2006; approved on June 7, 2007. This paper is part of the Journal of Irrigation and Drainage Engineering, Vol. 134, No. 2, April 1, 2008. CASCE, ISSN 0733-9437/2008/2-147$159 / \$ 25.00$ 
$\mathrm{ET}_{c}$ at progressive stages of crop development. Historically, grass and alfalfa have been used as the two reference surfaces for computing $\mathrm{ET}_{c}$ under a variety of climatic conditions. Ideally, using grass-reference ET $\left(\mathrm{ET}_{o}\right)$ or alfalfa-reference ET $\left(\mathrm{ET}_{r}\right)$ to quantify $\mathrm{ET}_{c}$ should result in similar values. There is no consensus on which reference surface should be chosen for a particular region, but the choice could be a function of climate characteristics of a local region or location. For example, alfalfa may be preferable for semiarid or arid climates because alfalfa tends to transpire water at potential rates even under advective environments. Also, alfalfa has a vigorous and deeper root structure and is, therefore, less likely to suffer water stress compared with a shallow-rooted grass crop. In places such as humid, subtropical climates where alfalfa is not commonly grown the grass reference may be preferable.

The $K_{c}$ values used to estimate $\mathrm{ET}_{c}$ change during the growing season and reflect the integrated effects of environmental, crop, and soil management factors such as leaf area, plant height, rate of crop development, crop planting date, and soil and weather conditions. All of these factors are imbedded in the $K_{c}$ values during the development of the coefficients. Under the same conditions, the ET rate for grass is usually less than for alfalfa, particularly under dry, hot, and windy conditions. Part of the reason for this is that the alfalfa crop that is taken as a reference is taller $(0.5 \mathrm{~m})$ than a grass-reference crop $(0.12 \mathrm{~m})$ and also has a greater leaf area (ASCE-EWRI 2005). Alfalfa also has greater aerodynamic and surface conductance (Wright et al. 2000). Thus, the $K_{c}$ values for a given crop will be smaller when alfalfa is used as a reference surface compared with the grass reference surface. The $K_{c}$ values for specific crops have been developed to be used with generally one of the two reference crops. Therefore, $K_{c}$ values for grass-reference $\left(K_{c o}\right)$ and alfalfa-reference $\left(K_{c r}\right)$ cannot be used interchangeably with $\mathrm{ET}_{r}$ or $\mathrm{ET}_{o}$ when computing $\mathrm{ET}_{c}$ and a correction factor would be necessary for adjustment.

Most agricultural weather station networks report either $\mathrm{ET}_{r}$ or $\mathrm{ET}_{o}$ values. For a local region the weather station network may be reporting $\mathrm{ET}_{r}$, but the $K_{c o}$ values may be more commonly available. In this case, either the weather network needs to report $\mathrm{ET}_{o}$ or the $K_{c o}$ values need to be converted to $K_{c r}$ values to determine $\mathrm{ET}_{c}$. Another important need to make the conversions arises when empirical temperature or radiation-based equations need to be used to determine $\mathrm{ET}_{c}$ from long-term climate data. Although the role of the "older" temperature or radiation-based models in ET estimations is somewhat diminishing they still have important roles to play under certain conditions. In some cases long-term (i.e., 50-60 years or longer) water use information is needed to asses the long-term hydrological balances of a given watershed and other purposes such as determining or assessing the sustainability and/or impact of the irrigation development. In this case one of the "older" noncombination equations has to be used because of the unavailability of all input parameters to solve one of the "modern" combination equations (i.e., FAO56-PM, ASCEPM) from the limited climate data. Thus, the "older" ET models have to be used with the appropriate $K_{c}$ values to determine $\mathrm{ET}_{c}$. However, if a grass-based "older" ET equation is being used to determine $\mathrm{ET}_{o}$ but measured $K_{c r}$ values are available locally, then the $K_{c r}$ values need to be converted to $K_{c o}$ to determine $\mathrm{ET}_{c}$. Although the user may have an option to use an "older" alfalfareference ET equation, in many cases the availability of the climate data necessary to compute $\mathrm{ET}_{o}$ or $\mathrm{ET}_{r}$ rather than the availability of the $K_{c}$ values dictates the decision on which the ET equation is used. Procedures are also needed to convert $\mathrm{ET}_{r}$ and $\mathrm{ET}_{o}$ values obtained with different $\mathrm{ET}_{\text {ref }}$ methods. A literature review revealed that there is no standard or suggested procedure for making the conversions between the two reference surfaces. An extremely limited number of $\mathrm{ET}_{r}$ to $\mathrm{ET}_{o}$ ratios $\left(K_{r}\right.$ values) reported in the literature are not consistent and show significant variations and they are limited to only one or two locations. For instance, Jensen et al. (1990) used $K_{r}=1.15$, but stated that this value did not fully reflect differences in climatic conditions among locations. The $K_{r}$ values could change with climate due to changes in aerodynamic $\left(r_{a}\right)$ and stomatal $\left(r_{s}\right)$ resistance. Allen et al. (1994) reported $K_{r}$ values from lysimeter sites for different climates, including six arid and five humid locations. The locations were classified as arid or humid if the mean daily relative humidity of the peak month was lower or greater than $60 \%$. Contrary to the $K_{r}$ values reported by Jensen et al. (1990) the average $K_{r}$ values ranged from 1.30 to 1.38 and from 1.12 to 1.39 for arid and humid locations, respectively. They reported that, in reality, air temperature, humidity, and wind speed above the evaporating surfaces are moderated by vapor flux and energy exchange at the surface. Therefore, calculated $K_{r}$ values may be $5-10 \%$ higher than those that occur under field conditions. They concluded that the average value of 1.20 to 1.25 rather than 1.15 may have been more representative of the lysimeter sites that were evaluated. Regardless of the absolute accuracy of the $K_{r}$ values obtained in their study, the variation among $K_{r}$ values suggests that the magnitude of $K_{c}$ values, when calculated as $K_{c}=\mathrm{ET}_{c} / \mathrm{ET}_{\text {ref }}$, can vary with climate. Literature review also revealed that the information is lacking on the magnitude of variation in $K_{r}$ values with the climate and the change in $K_{r}$ with the season within the same climatic conditions.

One procedure for estimating $K_{r}$ values as a function of some of the climate variables was proposed by Allen et al. (1998) as Eq. (68) in FAO56 Irrigation and Drainage Paper

$$
K_{r}=\mathrm{ET}_{r} / \mathrm{ET}_{o}=C+\left[0.04\left(U_{2}-2\right)-0.004\left(\mathrm{RH}_{\min }-45\right)\right](h / 3)^{0.3}
$$

where $C=$ coefficient that represents the $K_{c}$ value during the mid development period for alfalfa, and suggested as 1.05 for humid and calm conditions, 1.20 for semiarid and moderately windy conditions, and 1.35 for arid and windy conditions (Allen et al. 1998). The $U_{2}=$ average wind speed at $2 \mathrm{~m}$ height $\left(\mathrm{m} \mathrm{s}^{-1}\right)$, $\mathrm{RH}_{\text {min }}=$ minimum daily relative humidity during the midseason growth stage $(\%)$, and $h=$ standard height for the alfalfa-reference surface $(0.5 \mathrm{~m})$. Eq. (1) adjusts $K_{r}$ when $\mathrm{RH}_{\min }$ and $U_{2}$ differ from $45 \%$ and $2 \mathrm{~m} \mathrm{~s}^{-1}$. Wright et al. (2000) evaluated $K_{r}$ values obtained using Eq. (1) using lysimeter $\mathrm{ET}_{r}$ and $\mathrm{ET}_{o}$ measurements at Bushland, Tex. and Kimberly, Ida. They stated that obtaining $K_{r}$ values from $\mathrm{ET}_{r}$ and $\mathrm{ET}_{o}$ estimated from combination-based equations may be preferable to using Eq. (1). The $K_{r}$ values from Eq. (1) were approximately 3-8\% greater than values derived from lysimeter measurements, greater than values obtained with the Kimberly-Penman (Wright 1982) method, and lower than values estimated with the ASCE-PM method. Although the ideal and most accurate approach would be to derive $K_{r}$ values from local simultaneous lysimeter measurements of $\mathrm{ET}_{r}$ and $\mathrm{ET}_{o}$, local lysimeter data are extremely rare, and simultaneous measurements for the two reference crops rarely exist. Aforementioned studies show that the technical information on the dynamics of the $K_{r}$ values in different climatic conditions is lacking. Unanswered questions of interest include the evaluation of temporal and spatial variability of $K_{r}$ values, quantification of differences among $K_{r}$ values obtained with different $\mathrm{ET}_{\text {ref }}$ methods, and transferability of $K_{r}$ values among climatic regions. The objectives of 
Table 1. Coordinates, Elevation, and Years Studied for Each Location (from Dry to Humid)

\begin{tabular}{|c|c|c|c|c|c|}
\hline Location & Latitude $(\mathrm{N})$ & Longitude (W) & $\begin{array}{l}\text { Elevation } \\
(\mathrm{m})\end{array}$ & Years studied & $\begin{array}{l}\text { Reference } \\
\text { surface }\end{array}$ \\
\hline Phoenix, Ariz. & $33^{\circ} 28^{\prime}$ & $112^{\circ} 05^{\prime}$ & 335 & 1989-2004 & Grass \\
\hline Bushland, Tex. & $35^{\circ} 11^{\prime}$ & $102^{\circ} 06^{\prime}$ & 1,169 & 1997-2004 & Grass \\
\hline Davis, Calif. & $38^{\circ} 32^{\prime}$ & $121^{\circ} 46^{\prime}$ & 18 & 1990-2004 & Grass \\
\hline Clay Center, Neb. & $40^{\circ} 34^{\prime}$ & $98^{\circ} 08^{\prime}$ & 552 & 1983-2004 & Alfalfa \\
\hline Rockport, Mo. & $40^{\circ} 28^{\prime}$ & $95^{\circ} 29^{\prime}$ & 268 & 1992-2003 & Alfalfa \\
\hline Gainesville, Fla. & $29^{\circ} 38^{\prime}$ & $82^{\circ} 22^{\prime}$ & 29 & 1978-1990, 1994-2000 & Grass \\
\hline
\end{tabular}

this study were to: (1) develop $\mathrm{ET}_{r}$ to $\mathrm{ET}_{o}$ ratios $\left(K_{r}\right.$ values) for different climatic regions for the growing season and nongrowing (dormant) seasons; and (2) determine the variability (relative behavior) and seasonal trend of $K_{r}$ values within and between the locations to asses whether the $K_{r}$ values developed for one region can be used in other locations.

\section{Methods}

\section{Study Sites}

Daily $\mathrm{ET}_{r}$ and $\mathrm{ET}_{o}$ for several locations with different climatic characteristics were calculated using carefully screened daily weather data. Locations included a semiarid and windy location (Bushland, Tex.), a transition location between subhumid and semiarid with strong winds (Clay Center, Neb.), a location with a Mediterranean climate (Davis, Calif), a humid inland location with strong maritime and oceanic weather influences from the Gulf of Mexico and Atlantic Ocean (Gainesville, Fla.), an aridtemperate location (Phoenix, Ariz.), and an inland humid location (Rockport, Mo). Latitude, longitude, elevation, years studied, and representative reference crop for each site are given in Table 1. Although few in number, these locations represented the diversity of climates needed to address the objectives of the study.

\section{Weather Data Sets}

Daily weather data sets for Bushland were measured by the USDA-ARS Conservation and Production Research Laboratory at the ET research facility at Bushland, Tex. Clay Center datasets were measured by the High Plains Regional Climate Center (HPRCC 2006) at the University of Nebraska-Lincoln, South Central Agricultural Laboratory, located approximately $150 \mathrm{~km}$ west of Lincoln, near Clay Center, Neb. The ET $r$ values for Clay Center were obtained directly from the HPRCC. Datasets at Rockport were also obtained from the HPRCC. Datasets for Davis were obtained from the California Department of Water Resources, California Irrigation Management Information System
(CIMIS 2006) website (Snyder and Pruitt 1985, 1992). Climate data for Gainesville were measured at the Green Acres Agricultural Research and Extension Center weather station located approximately $8 \mathrm{~km}$ north of Gainesville in north central Florida (Irmak et al. 2003). Datasets at Phoenix were obtained from the Arizona Meteorological Network, (AZMET 2006). Daily weather variables recorded at the stations included maximum and minimum air temperature $\left(T_{\max }\right.$ and $\left.T_{\min }\right)$, maximum and minimum relative humidity $\left(\mathrm{RH}_{\max }\right.$ and $\left.\mathrm{RH}_{\text {min }}\right)$, wind speed and direction, precipitation, and solar radiation $\left(R_{s}\right)$. The type of instrumentation and placement heights for each site are listed in Table 2. Although the same types and model of instrumentation may not have been used for the entire study periods for each location and may have changed over the years, the instrumentation type, model, and placement height that are listed in Table 2 represent the most recently used instrumentation and placement for a given station. Long-term average values of some of the weather variables for each study location are given in Table 3 .

\section{Data Quality Control and Calculation of Daily ETo and $E T_{r}$ Values}

The accuracy of the computed $\mathrm{ET}_{\text {ref }}$ can be impacted substantially by the quality of the weather data used (Allen 1996; Itenfisu et al. 2003). Data quality checks have been recommended and procedures for the quality assessment of the datasets used to compute $\mathrm{ET}_{\text {ref }}$ have been given by Allen (1996), Allen et al. (1998), ASCE-EWRI (2005), Droogers and Allen (2002), and Temesgen et al. (1999). In this study, quality and integrity checks were made for $T_{\max }, T_{\min }, \mathrm{RH}_{\max }, \mathrm{RH}_{\min }$, and $R_{s}$ for all datasets. Data quality analyses were not conducted for wind speed. Three years of data (1991-1993) from the Gainesville station were judged to be in poor quality and were excluded from the analyses and all other datasets used in this study were judged to be of good quality.

Daily $\mathrm{ET}_{o}$ and $\mathrm{ET}_{r}$ values were calculated using the "standardized" ASCE-PM equation following the procedures outlined by ASCE-EWRI (2005). The standardized ASCE-PM equation was intended to simplify and clarify the application of the method and

Table 2. Instrument Type and Installation Height at Study Sites

\begin{tabular}{lcccccc}
\hline Variable $^{\mathrm{a}}$ & Phoenix & Bushland, Tex. & Davis, Calif. & Clay Center, Neb. & Rockport, Mo. & Gainesville, Fla. \\
\hline$R_{s}{ }^{\mathrm{b}}$ & LI200S pyranometer & Epply PSP pyranometer & LI200S pyranometer & LI200X pyranometer & LI200X pyranometer & LI200X pyranometer \\
$T$ and RH & HMP45C probe $/ 1.5 \mathrm{~m}$ & HMP45C probe/1.5 m & HMP35C probe/1.5 m & HMP35 probe/1.5 m & HMP35 probe/1.5 m & HMP 35C probe/1.5 m \\
$U$ & Met-One anemo./3 m & Met-One anemo./2 m & Met-One anemo./2 m & Met-One anemo./3 m & Met-One anemo./3 m & Handar 425A/1 m \\
Rainfall & RG 250 tip. buck. & TE525MM tip. buck. & TE525MM tip. buck. & TE525MM tip. buck. & TE525MM tip. buck. & TE525MM tip. buck. \\
\hline
\end{tabular}

${ }^{\mathrm{a}} R_{s}=$ solar radiation, $T=$ air temperature, $\mathrm{RH}=$ relative humidity, $U=$ wind speed.

${ }^{\mathrm{b}}$ LI200X, LI200S from LiCor Corp., Lincoln Neb; HMP, HMP45C, HMP35C from Campbell Sci., Inc., Logan, Utah; Handar 425A from Vaisala Corp.-Handar Business Unit, Sunnyvale, Calif.; TE525MM from Texas Electronics, Inc., Dallas; Epply PSP from The Epply Laboratory Inc., Newport, R.I.; Met-One from Met-One, Grants Pass, Ore.; and RG2501 from Sierra Misco (SM) Technical Consultants Inc., Richmond, Calif. 
Table 3. Long-Term Monthly Average Climatic Information Including Wind Speed at $2 \mathrm{~m}\left(U_{2}, \mathrm{~m} \mathrm{~s}^{-1}\right)$, Maximum and Minimum Air Temperatures $\left(T_{\max }\right.$ and $\left.T_{\min },{ }^{\circ} \mathrm{C}\right)$, Average Relative Humidity $\left(\mathrm{RH}_{\text {avg }}, \%\right)$, Incoming Solar Radiation $\left(R_{s}, \mathrm{MJ} \mathrm{m}^{-2} \mathrm{day}^{-1}\right)$, and Monthly Total Rainfall (Rain, mm) for Study Locations

\begin{tabular}{|c|c|c|c|c|c|c|c|c|c|c|c|c|c|}
\hline Site & $\begin{array}{l}\text { Climate } \\
\text { variable }\end{array}$ & January & February & March & April & May & June & July & August & September & October & November & December \\
\hline \multirow[t]{6}{*}{ Bushland, Tex. } & $U_{2}$ & 4.7 & 5.0 & 5.3 & 5.4 & 5.2 & 5.1 & 4.4 & 4.0 & 4.3 & 4.6 & 4.6 & 4.8 \\
\hline & $T_{\max }$ & 11.1 & 12.7 & 16.6 & 21.3 & 27.1 & 30.7 & 33.1 & 31.9 & 28.6 & 22.4 & 16.0 & 10.5 \\
\hline & $T_{\min }$ & -4.0 & -2.6 & 0.4 & 5.0 & 10.9 & 15.8 & 18.4 & 17.3 & 13.4 & 7.5 & 3.2 & -4.2 \\
\hline & $\mathrm{RH}_{\text {avg }}$ & 59.1 & 59.3 & 58.6 & 56.3 & 54.9 & 57.6 & 55.8 & 58.9 & 57.9 & 61.4 & 59.5 & 61.3 \\
\hline & $R_{s}$ & 10.6 & 13.4 & 17.7 & 21.1 & 25.3 & 25.5 & 26.1 & 22.8 & 19.6 & 14.8 & 10.8 & 10.0 \\
\hline & Rain & 9.0 & 14.0 & 44.0 & 44.0 & 30.0 & 57.0 & 37.0 & 49.0 & 32.0 & 54.0 & 22.0 & 11.0 \\
\hline \multirow[t]{6}{*}{ Clay Center, Neb. } & $U_{2}$ & 3.6 & 3.7 & 4.1 & 4.4 & 4.0 & 3.5 & 2.9 & 2.6 & 3.1 & 3.3 & 3.7 & 3.6 \\
\hline & $T_{\max }$ & 2.4 & 4.5 & 10.5 & 17.0 & 22.5 & 28.1 & 30.3 & 29.2 & 25.3 & 18.3 & 9.3 & 3.1 \\
\hline & $T_{\min }$ & -10.1 & -8.0 & -3.2 & 2.4 & 9.3 & 14.6 & 17.3 & 16.3 & 10.7 & 3.6 & -3.6 & -9.0 \\
\hline & $\mathrm{RH}_{\text {avg }}$ & 73.8 & 73.6 & 69.8 & 66.3 & 71.3 & 70.2 & 73.2 & 74.5 & 68.8 & 67.2 & 71.9 & 74.5 \\
\hline & $R_{s}$ & 7.5 & 10.1 & 13.5 & 16.9 & 19.4 & 22.4 & 22.4 & 19.7 & 15.9 & 11.3 & 7.5 & 6.4 \\
\hline & Rain & 10.0 & 23.0 & 40.0 & 59.0 & 112.0 & 110.0 & 93.0 & 83.0 & 63.0 & 45.0 & 32.0 & 18.0 \\
\hline \multirow[t]{6}{*}{ Davis, Calif. } & $U_{2}$ & 2.6 & 2.7 & 2.7 & 3.0 & 2.9 & 3.0 & 2.6 & 2.5 & 2.4 & 2.6 & 2.4 & 2.6 \\
\hline & $T_{\max }$ & 12.6 & 15.6 & 19.2 & 22.2 & 26.3 & 30.2 & 32.8 & 32.6 & 31.2 & 26.1 & 17.8 & 12.6 \\
\hline & $T_{\min }$ & 3.8 & 4.9 & 6.2 & 7.5 & 10.2 & 12.6 & 13.8 & 13.3 & 12.4 & 9.5 & 5.6 & 3.1 \\
\hline & $\mathrm{RH}_{\text {avg }}$ & 83.6 & 77.5 & 70.5 & 61.4 & 60.3 & 57.0 & 57.5 & 57.0 & 53.8 & 54.6 & 70.4 & 80.2 \\
\hline & $R_{s}$ & 6.5 & 10.3 & 16.2 & 21.6 & 25.3 & 28.8 & 28.9 & 26.0 & 20.8 & 14.7 & 9.1 & 6.4 \\
\hline & Rain & 97.0 & 113.0 & 62.0 & 23.0 & 20.0 & 7.0 & 2.0 & 2.0 & 3.0 & 18.0 & 44.0 & 84.0 \\
\hline \multirow[t]{6}{*}{ Gainesville, Fla. } & $U_{2}$ & 1.5 & 1.8 & 1.8 & 1.6 & 1.4 & 1.2 & 1.0 & 1.0 & 1.1 & 1.3 & 1.2 & 1.2 \\
\hline & $T_{\max }$ & 19.6 & 21.7 & 24.7 & 27.6 & 31.1 & 32.9 & 33.4 & 33.2 & 31.6 & 28.4 & 24.8 & 20.8 \\
\hline & $T_{\min }$ & 5.6 & 7.3 & 9.9 & 12.5 & 16.8 & 20.3 & 21.6 & 21.6 & 20.1 & 15.4 & 11.3 & 7.4 \\
\hline & $\mathrm{RH}_{\mathrm{avg}}$ & 75.4 & 74.6 & 73.5 & 72.1 & 73.4 & 78.1 & 79.8 & 79.6 & 78.9 & 76.5 & 75.5 & 76.3 \\
\hline & $R_{s}$ & 10.3 & 12.6 & 16.6 & 20.2 & 21.4 & 20.1 & 19.3 & 17.8 & 14.9 & 14.0 & 11.4 & 9.3 \\
\hline & Rain & 102.0 & 94.0 & 104.0 & 85.0 & 79.0 & 151.0 & 165.0 & 182.0 & 148.0 & 65.0 & 66.0 & 69.0 \\
\hline \multirow[t]{6}{*}{ Phoenix, Ariz. } & $U_{2}$ & 0.9 & 1.1 & 1.2 & 1.5 & 1.5 & 1.4 & 1.5 & 1.4 & 1.2 & 1.0 & 0.9 & 0.9 \\
\hline & $T_{\max }$ & 20.2 & 21.5 & 24.9 & 28.7 & 33.8 & 38.6 & 39.9 & 39.3 & 37.2 & 31.4 & 24.0 & 19.5 \\
\hline & $T_{\min }$ & 4.2 & 6.1 & 8.8 & 12.1 & 16.5 & 20.2 & 24.5 & 24.8 & 21.0 & 14.0 & 7.1 & 3.4 \\
\hline & $\mathrm{RH}_{\mathrm{avg}}$ & 56.1 & 52.4 & 49.4 & 41.3 & 36.1 & 34.1 & 41.4 & 46.4 & 48.3 & 48.5 & 52.9 & 57.1 \\
\hline & $R_{s}$ & 11.0 & 14.3 & 19.6 & 25.5 & 28.5 & 29.9 & 27.3 & 24.9 & 21.7 & 17.3 & 12.6 & 10.3 \\
\hline & Rain & 25.0 & 26.0 & 26.0 & 7.0 & 2.0 & 0.0 & 31.0 & 27.0 & 22.0 & 15.0 & 16.0 & 21.0 \\
\hline \multirow[t]{6}{*}{ Rockport, Mo. } & $U_{2}$ & 3.1 & 3.2 & 3.4 & 3.8 & 3.1 & 2.8 & 2.3 & 2.2 & 2.5 & 2.9 & 3.1 & 3.0 \\
\hline & $T_{\max }$ & 2.4 & 5.9 & 11.7 & 18.1 & 23.8 & 28.6 & 30.8 & 30.4 & 26.0 & 19.5 & 10.5 & 4.4 \\
\hline & $T_{\min }$ & -8.2 & -5.1 & -1.1 & 5.5 & 11.6 & 17.0 & 19.9 & 18.8 & 12.3 & 6.5 & -0.6 & -5.8 \\
\hline & $\mathrm{RH}_{\text {avg }}$ & 75.6 & 73.6 & 66.7 & 66.3 & 69.3 & 73.6 & 76.5 & 75.6 & 69.9 & 68.1 & 72.5 & 76.6 \\
\hline & $R_{s}$ & 6.7 & 9.3 & 13.9 & 15.9 & 19.2 & 22.0 & 22.0 & 19.8 & 16.0 & 11.3 & 7.1 & 6.0 \\
\hline & Rain & 18.0 & 27.0 & 41.0 & 80.0 & 124.0 & 132.0 & 137.0 & 56.0 & 77.0 & 63.0 & 48.0 & 17.0 \\
\hline
\end{tabular}

associated equations for computing aerodynamic $\left(r_{a}\right)$ and bulk surface resistance (stomatal resistance) $\left(r_{s}\right)$ (Irmak et al. 2005). Equations for two different reference surfaces were combined into a single expression with different coefficients for grass and alfalfa-reference, and for daily or hourly time steps (Itenfisu et al. 2003; Walter et al. 2001). The "standardized" ASCE-PM equation for both reference surfaces is

$$
\mathrm{ET}_{\text {ref }}=\frac{0.408 \Delta\left(R_{n}-G\right)+\gamma \frac{C_{n}}{T+273} U_{2}\left(e_{s}-e_{a}\right)}{\left[\Delta+\gamma\left(1+C_{d} U_{2}\right)\right]}
$$

where $\mathrm{ET}_{\text {ref }}=$ standardized reference ET $\left(\mathrm{mm} \mathrm{day}^{-1}\right) ; \Delta=$ slope of saturation vapor pressure versus air temperature curve $\left(\mathrm{kPa}^{\circ} \mathrm{C}^{-1}\right)$; $R_{n}=$ calculated net radiation at the crop surface $\left(\mathrm{MJ} \mathrm{m}^{-2}\right.$ day $\left.^{-1}\right)$; $G=$ heat flux density at the soil surface (zero for daily time step); $T=$ mean daily air temperature at $1.5-2.5 \mathrm{~m}$ height $\left({ }^{\circ} \mathrm{C}\right) ; U_{2}$
$=$ mean daily wind speed at $2 \mathrm{~m}$ height $\left(\mathrm{m} \mathrm{s}^{-1}\right) ; e_{s}=$ saturation vapor pressure $(\mathrm{kPa}) ; e_{a}=$ actual vapor pressure $(\mathrm{kPa}) ; \gamma$ $=$ psychrometric constant $\left(\mathrm{kPa}^{\circ} \mathrm{C}^{-1}\right) ; C_{n}$ and $C_{d}$, respectively, $=$ numerator and denominator constants that change with reference surface and calculation time step; and $0.408=$ coefficient $\left(\mathrm{m}^{2} \mathrm{~mm} \mathrm{MJ}{ }^{-1}\right)$. Wind speed measurements that were made other than at the $2 \mathrm{~m}$ height were converted to $2 \mathrm{~m}$ wind speed values using Eq. (47) in Allen et al. (1998) and all other parameters/ variables in Eq. (2) were computed using the procedures given in ASCE-EWRI (2005). The values of $C_{n}$ and $C_{d}$ for the grass and alfalfa-reference surfaces and for daily time steps are given in Table 4 . The $C_{n}$ values account for the time step and aerodynamic resistance of the reference surface and $C_{d}$ accounts for the time step, bulk surface resistance, and aerodynamic resistance of the reference surface (ASCE-EWRI 2005).

In addition to the $\mathrm{ASCE}_{-\mathrm{PM} \mathrm{ET}}$ and $\mathrm{ET}_{o}$ values, daily $\mathrm{ET}_{r}$ 
Table 4. Values for $C_{n}$ and $C_{d}$ in Eq. (2) for Daily Time Step for Grass and Alfalfa-Reference Surfaces (ASCE-EWRI 2005)

\begin{tabular}{ccccc}
\hline \multicolumn{2}{c}{ Grass reference $\left(\mathrm{ET}_{o}\right)$} & & \multicolumn{2}{c}{ Alfalfa reference $\left(\mathrm{ET}_{r}\right)$} \\
\cline { 1 - 2 } \cline { 5 - 6 }$C_{n}$ & $C_{d}$ & & $C_{n}$ & $C_{d}$ \\
\hline 9.00 & 0.34 & & 1,600 & 0.38 \\
\hline
\end{tabular}

values were computed with four other $\mathrm{ET}_{r}$ methods that are described in Burman and Pochop (1994) and Jensen et al. (1990). Therefore, a detailed description of each method is not given and the reader is referred to original sources. For the $\mathrm{ET}_{r}$ equations other than ASCE-PM, the procedures on calculation of the equation parameters associated with each equation were used. The methods were: (1) Jensen-Haise (Jensen and Haise 1963); (2) 1972 Kimberly-Penman (Wright and Jensen 1972); (3) 1982 Kimberly-Penman (Wright 1982); and (4) the HPRCC-Penman equation. These models were selected because they represent the majority of the alfalfa-reference ET equations that are currently being used in different applications. In this study, the HPRCCPenman equation was used only at Clay Center. The HPRCC equation is a Penman-type (Penman 1948) combination equation and was modified for Nebraska (Mitchell, Neb.) climatic conditions by Kincaid and Heerman (1974) and has been adopted by the HPRCC and has been widely used in North Dakota, Nebraska, Kansas, South Dakota, and Colorado as part of the HPRCC automated weather network.

The standardized ASCE-PM method was used as the basis for comparisons with all the other methods. First, daily $\mathrm{ET}_{r}$ values were compared with the standardized ASCE-PM ET $r$ values. Discrepancies in $\mathrm{ET}_{r}$ values obtained with different methods compared with the ASCE-PM method were quantified using the rootmean-square difference (RMSD). The four $\mathrm{ET}_{\text {ref }}$ methods were also compared to the ASCE-PM method by linear regression analysis from which the coefficient of determination $\left(r^{2}\right)$, slope, and intercept were calculated. A statistical analysis of equality of the regression line (slope) to unity was conducted to identify whether the $\mathrm{ET}_{r \text { (method) }}$ values were significantly different than the ASCE-PM ET $_{r}$ values at the $95 \%$ confidence level. Analyses were conducted for both the calendar year and the growing season. Although the growing season varies with location, for consistency, it was considered to be from May 1 to September 30 for all locations.

\section{Calculating $K_{r}$ Values}

Daily $K_{r}$ values were calculated from measured climate datasets. Monthly average $K_{r}$ values that were obtained from averaging daily $K_{r}$ values for each month were calculated using two different approaches. First, Eq. (1) was used to calculate $K_{r}$ values on a daily basis for each study site. Coefficient $C$ was taken as 1.25 , $1.23,1.20,1.05,1.35$, and 1.05 for Bushland, Clay Center, Davis, Gainesville, Phoenix, and Rockport. Daily $\mathrm{RH}_{\min }$ and $U_{2}$ values were used in the calculations. Daily $K_{r}$ values were calculated for calendar year and growing season. To determine year-to-year variability and to quantify the measure of how widely the values were dispersed from the average $K_{r}$ values, the standard deviation (SD) between long-term and individual years' SD values were calculated. The following second approach was used to calculate the ratio of $\mathrm{ET}_{r}$ over $\mathrm{ET}_{o}$ to determine $K_{r}$

$$
K_{r}=\mathrm{ET}_{r \text { (method) }} /\left(\mathrm{ASCE}-\mathrm{PM} \mathrm{ET}_{o}\right)
$$

One of the differences between Eqs. (1) and (3) is that the FAO56 $K_{r}$ procedure computes $K_{r}$ values as a function of $\mathrm{RH}_{\text {min }}, U_{2}$, and a local coefficient $(C)$, and does not account for the evapotranspiration differences between two reference surfaces (alfalfa and grass). However, Eq. (3) computes $K_{r}$ values as a direct function of $\mathrm{ET}_{\text {ref }}$ and accounts for the relative ratio of the two different surfaces (alfalfa and grass) under the same climatic environment simultaneously. In the second approach, the following equations were used to calculate $K_{r}$ values for each $\mathrm{ET}_{r}$ method on a daily basis: ASCE-PM:

$$
K_{r}=\frac{\mathrm{ET}_{r(\mathrm{ASCE}-\mathrm{PM})}}{\mathrm{ET}_{o(\mathrm{ASCE}-\mathrm{PM})}}
$$

1963 Jensen-Haise (1963J-H):

$$
K_{r}=\frac{\mathrm{ET}_{r(1963 \mathrm{~J}-\mathrm{H})}}{\mathrm{ET}_{o(\text { ASCE-PM })}}
$$

HPRCC:

$$
K_{r}=\frac{\mathrm{ET}_{r_{(\mathrm{HPRCC})}}}{\mathrm{ET}_{o(\mathrm{ASCE}-\mathrm{PM})}}
$$

1972 Kimberly-Penman (1972 Kim-Pen):

$$
K_{r}=\frac{\mathrm{ET}_{r(1972 \mathrm{Kim}-\mathrm{Pen})}}{\mathrm{ET}_{o(\mathrm{ASCE}-\mathrm{PM})}}
$$

1982 Kimberly-Penman (1982 Kim-Pen):

$$
K_{r}=\frac{\mathrm{ET}_{r(1982 \mathrm{Kim}-\mathrm{Pen})}}{\mathrm{ET}_{o(\text { ASCE }-\mathrm{PM})}}
$$

\section{Results and Discussion}

\section{Comparison of $E T_{r(m e t h o d)}$ and $E T_{r(A S C E-P M)}$ Values}

It is important to asses the relative behavior of each $\mathrm{ET}_{r}$ method as compared to the ASCE-PM ET $r$ values before computing $K_{r}$ values because the robustness of the $K_{r}$ values calculated from different $\mathrm{ET}_{r}$ methods, in part, will be a function of how well their $\mathrm{ET}_{r}$ estimates compare with the ASCE-PM ET ${ }_{r}$ values. The performance indicators and statistical analyses of comparisons of $\mathrm{ET}_{r}$ values from each method with the ASCE-PM ET $r$ values are given in Table 5. The regression parameters for the calendar year and growing season for each method and location are included in Table 5.

\section{Jensen-Haise $E T_{r}$}

The $1963 \mathrm{~J}_{-\mathrm{H} \mathrm{ET}_{r}}$ estimates were poor compared with the ASCE-PM ET $r$ values. The method underestimated at Bushland, Clay Center, Davis, and Rockport (Table 5) and overestimated at Gainesville and Phoenix. The method provided reasonable estimates only at Phoenix $\left[r^{2}=0.90, \mathrm{RMSD}=1.11 \mathrm{~mm} \mathrm{day}^{-1}\right.$ for calendar year, (C.Y.) $]$ and Gainesville $\left(r^{2}=0.72\right.$, RMSD $=1.17 \mathrm{~mm} \mathrm{day}^{-1}$ for C.Y.). The reasonable estimates at Phoenix and Gainesville might be due to the low wind speeds at these locations. This method does not account for wind speed, which may significantly affect the ET rate in some climates. In climates 
Table 5. Root-Mean-Square Difference (RMSD) of Daily ET $r$ Estimates, Regression Coefficients between ASCE-PM ET $r$ and ET $r$ (method), and Test for Equality of Regression Line for Unity for Calendar Year (C.Y.) and Growing Season (G.S.)

\begin{tabular}{|c|c|c|c|c|c|c|c|c|c|}
\hline $\begin{array}{l}\text { Location and } \mathrm{ET}_{r} \\
\text { methods }\end{array}$ & $\begin{array}{c}\text { RMSD }^{\mathrm{a}} \\
\text { of daily } \\
\text { estimate for } \\
\text { C.Y. } \\
\left(\mathrm{mm} \mathrm{day}^{-1}\right)\end{array}$ & $\begin{array}{l}\text { Slope }^{b} \\
\text { (C.Y.) }\end{array}$ & Intercept $^{\mathrm{b}}$ (C.Y.) & $\begin{array}{c}r^{2} \\
\text { (C.Y.) }\end{array}$ & $\begin{array}{l}\text { Test for } \\
\text { equality of } \\
\text { regression } \\
\text { line for C.Y. } \\
(t \text { value })\end{array}$ & $\begin{array}{l}\text { RMSD of daily } \\
\text { estimate and test } \\
\text { for equality for } \\
\text { G.S. } \\
\left(\mathrm{mm} \mathrm{day}^{-1}\right)\end{array}$ & $\begin{array}{l}\text { Slope }^{b} \\
\text { (G.S.) }\end{array}$ & $\begin{array}{l}\text { Intercept }^{\mathrm{b}} \\
\text { (G.S.) }\end{array}$ & $\begin{array}{c}r^{2} \\
\text { (G.S.) }\end{array}$ \\
\hline \multicolumn{10}{|l|}{ Bushland, Tex. } \\
\hline 1963 Jensen-Haise & 4.36 & 0.59 & -0.65 & 0.74 & $91.19^{\mathrm{c}}$ & $4.51(1,224)^{\mathrm{c}}$ & 0.42 & 2.06 & 0.63 \\
\hline 1972 Kimberly-Penman & 0.87 & 1.01 & 0.47 & 0.97 & $-44.13^{c}$ & $0.79(1,224)^{\mathrm{c}}$ & 1.00 & 0.44 & 0.97 \\
\hline 1982 Kimberly-Penman & 1.08 & 0.97 & -0.30 & 0.95 & $32.1^{\mathrm{c}}$ & $(\boldsymbol{P}=\mathbf{0 . 4 4})^{\mathrm{d}}(1,224)$ & 0.92 & 0.82 & 0.96 \\
\hline \multicolumn{10}{|l|}{ Clay Center, Neb. } \\
\hline 1963 Jensen-Haise & 2.23 & 0.76 & -0.61 & 0.74 & $99.26^{\mathrm{c}}$ & $1.95(3,366)^{\mathrm{c}}$ & 0.67 & 0.80 & 0.64 \\
\hline 1974 HPRCC Penman & 0.56 & 0.94 & 0.04 & 0.97 & $37.03^{\mathrm{c}}$ & $0.63(3,366)^{\mathrm{c}}$ & 0.93 & 0.17 & 0.95 \\
\hline 1972 Kimberly-Penman & 0.48 & 1.00 & 0.24 & 0.98 & $-62.98^{\mathrm{c}}$ & $0.47(3,366)^{\mathrm{c}}$ & 0.98 & 0.41 & 0.98 \\
\hline 1982 Kimberly-Penman & 0.67 & 0.98 & -0.08 & 0.95 & $25.09^{\mathrm{c}}$ & $0.51(3,366)^{\mathrm{c}}$ & 0.96 & 0.46 & 0.97 \\
\hline \multicolumn{10}{|l|}{ Davis, Calif. } \\
\hline 1963 Jensen-Haise & 2.23 & 0.71 & -0.03 & 0.82 & $78.32^{\mathrm{c}}$ & $2.36(2,295)^{\mathrm{c}}$ & 0.56 & 1.89 & 0.58 \\
\hline 1972 Kimberly-Penman & 0.41 & 0.97 & 0.16 & 0.99 & $(\boldsymbol{P}=\mathbf{0 . 0 7})^{\mathrm{d}}$ & $0.46(2,295)^{\mathrm{c}}$ & 0.92 & 0.58 & 0.96 \\
\hline 1982 Kimberly-Penman & 0.80 & 0.99 & -0.31 & 0.96 & $39.68^{c}$ & $(\boldsymbol{P}=\mathbf{0 . 0 6})^{\mathrm{d}}(2,295)$ & 0.93 & 0.53 & 0.91 \\
\hline \multicolumn{10}{|l|}{ Gainesville, Fla. } \\
\hline 1963 Jensen-Haise & 1.17 & 1.17 & -0.50 & 0.73 & $-11.54^{\mathrm{c}}$ & $1.33(3,060)^{\mathrm{c}}$ & 1.17 & 0.11 & 0.72 \\
\hline 1972 Kimberly-Penman & 0.24 & 1.02 & 0.10 & 0.99 & $-83.67^{\mathrm{c}}$ & $0.27(3,060)^{\mathrm{c}}$ & 1.02 & 0.16 & 0.99 \\
\hline 1982 Kimberly-Penman & 0.54 & 1.07 & -0.32 & 0.91 & $6.49^{c}$ & $0.55(3,060)^{\mathrm{c}}$ & 1.08 & 0.06 & 0.94 \\
\hline \multicolumn{10}{|l|}{ Phoenix, Ariz. } \\
\hline 1963 Jensen-Haise & 1.11 & 1.08 & -0.64 & 0.90 & $11.16^{\mathrm{c}}$ & $1.21(2,448)^{\mathrm{c}}$ & 0.84 & 1.80 & 0.62 \\
\hline 1972 Kimberly-Penman & 0.29 & 0.94 & 0.37 & 0.99 & $(\boldsymbol{P}=\mathbf{0 . 0 9})^{\mathrm{d}}$ & $0.34(2,448)^{\mathrm{c}}$ & 0.86 & 1.02 & 0.98 \\
\hline 1982 Kimberly-Penman & 0.83 & 1.12 & -0.92 & 0.96 & $23.3^{\mathrm{c}}$ & $0.86(2,448)^{\mathrm{c}}$ & 1.08 & -0.32 & 0.85 \\
\hline \multicolumn{10}{|l|}{ Rockport, Mo. } \\
\hline 1963 Jensen-Haise & 1.93 & 0.83 & -0.52 & 0.71 & $52.68^{\mathrm{c}}$ & $1.51(1,836)^{\mathrm{c}}$ & 0.78 & 0.77 & 0.64 \\
\hline 1972 Kimberly-Penman & 0.36 & 1.01 & 0.14 & 0.99 & $-40.22^{c}$ & $0.36(1,836)^{\mathrm{c}}$ & 0.99 & 0.31 & 0.98 \\
\hline 1982 Kimberly-Penman & 0.67 & 0.97 & -0.06 & 0.94 & $19.18^{\mathrm{c}}$ & $0.53(1,836)^{\mathrm{c}}$ & 0.96 & 0.47 & 0.95 \\
\hline
\end{tabular}

${ }^{a}$ RMSD was calculated from daily $\mathrm{ET}_{r}$ values for each method.

${ }^{\mathrm{b}}$ Regression coefficients where $\mathrm{ET}_{r}$ (method) $=$ slope $\times \mathrm{ASCE}_{\mathrm{PM}} \mathrm{ET}_{r}+$ intercept.

${ }^{c}$ Values in parenthesis indicate number of observations for the growing season. For a given location, all days from May through September in each year were included in the analyses. C.Y. $=$ Calendar year, G.S. $=$ Growing season (May-September).

${ }^{\mathrm{d}}$ The slope of the regression line between the $\mathrm{ET}_{r}$ (method) values and the ASCE-PM ET $r$ values is significantly different $(P<0.05)$ than the unity at the 5\% significance level. The $t$ values were reported only for calendar year analyses. The significance of the regression line was reported for the growing season analyses.

with strong winds, the saturated air above the plant canopy will be constantly replaced with drier air, increasing vapor pressure deficit and ET. However, in calm wind conditions, the saturated air in the immediate surrounding of the crop canopy may not be replaced as often, making ET less sensitive to wind speed. In climates with high humidity and low winds, the saturated air above the canopy can be replaced with only slightly less humid air. Thus, one would expect the $1963 \mathrm{~J}-\mathrm{H}$ equation to provide better estimates of $\mathrm{ET}_{r}$ in environments with calm winds compared with environments with strong winds. The $1963 \mathrm{~J}^{-\mathrm{H} \mathrm{ET}} \mathrm{ET}_{r}$ estimates were significantly different than the ASCE-PM ET $r$ values at all locations. The magnitude of underestimations at Bushland, Clay Center, and Davis increased at high ET values $(\geqslant 10 \mathrm{~mm})$. The method overestimated the ASCE-PM ET $r$ values by 8 and $17 \%$ at Phoenix and Gainesville (Table 5). The underestimation was $24 \%$ at Clay Center, which was in agreement with the value observed by Jensen et al. (1990) as 30\% underestimations by this method at an arid and windy location (Scottsbluff, Neb.). Estimations for the growing season resulted in lower RMSD values at Clay Center and Rockport.

\section{HPRCC Penman ETr}

The HPRCC Penman $\mathrm{ET}_{r}$ values were used and analyzed only at Clay Center. The method provided good estimates with a high $r^{2}$ value of 0.97 and low RMSD of $0.56 \mathrm{~mm} \mathrm{day}^{-1}$. Estimates were parallel to the ASCE-PM ET $r$ values for the majority of the data range. However, the equation did not respond to the changes in $\mathrm{ET}_{r}$ values greater than approximately $10 \mathrm{~mm}$ and the magnitudes of underestimations were larger at the higher $\mathrm{ET}_{r}$ rates. Overall, estimations were within $6 \%$ of the ASCE-PM ET $r$ values. The RMSD value $\left(0.63 \mathrm{~mm} \mathrm{day}^{-1}\right)$ for the growing season was higher than for the calendar year $\left(0.56 \mathrm{~mm} \mathrm{day}^{-1}\right)$ with similar slopes (0.94 versus 0.93). The consistent lagging of the HPRCC $\mathrm{ET}_{r}$ values below the ASCE-PM ET $r$ values at high ET values indicates calibration characteristics. The HPRCC Penman equation was modified by Kincaid and Heermann (1974) for Mitchell, Neb, climatic conditions by changing the wind function of the original Penman (1948) method. Kincaid and Heermann (1974) stated that the coefficients used in the wind function of the HPRCC Penman equation were nearly the same as those reported by Jensen (1969) 
for Twin Falls, Id. However, in practical application, the HPRCC $\mathrm{ET}_{r}$ differs from the original equation of Kincaid and Heerman (1974). In practical application of the original equation by the HPRCC, the maximum value of wind speed and vapor pressure deficit (VPD) $\left[e_{s}-e_{a}\right.$ in Eq. (2)] that can occur is limited to certain values. Thus, the equation does not respond to the effect of the wind speed and VPD on $\mathrm{ET}_{r}$ after an approximately $\mathrm{ET}_{r}$ value of $\geqslant 10 \mathrm{~mm}$. The $\mathrm{ET}_{r}$ calculations reported by HPRCC in the daily weather data sets are made using a VPD limit of $2.3 \mathrm{kPa}$ and wind speed limit of $5.1 \mathrm{~m} \mathrm{~s}^{-1}$ as suggested by Hubbard (1992). These two conditions are the main cause of discrepancies between the HPRCC and the ASCE-PM ET $r$ values at high $\mathrm{ET}_{r}$ rates $(\geqslant 10 \mathrm{~mm})$. These two conditions will cause some faulty $\mathrm{ET}_{r}$ values by the HPRCC Penman. Because the climatic conditions of the VPD above $2.3 \mathrm{kPa}$ and wind speeds above $5.1 \mathrm{~m} \mathrm{~s}^{-1}$ are often observed in many parts of Nebraska, especially during the growing season, the VPD and wind speeds above these limits can be a substantial portion of the climate datasets in some parts of the state during hot, dry, and windy periods. These large VPDs and high wind speeds represent natural climatic demand for evaporative losses of the environment and should be reflected in the $\mathrm{ET}_{r}$ estimates. Eliminating the conditions on upper limits of the VPD and wind speed would greatly improve the performance of the HPRCC Penman equation at high ET rates as compared with the ASCE-PM ET $r$.

\section{2 and 1982 Kimberly-Penman ETr}

The 1972 Kim-Pen had the best agreement with the ASCE-PM at all locations. The $\mathrm{ET}_{r}$ estimates correlated very well with the ASCE-PM ET $r$ values throughout the year, with low RMSD values of $0.87,0.48,0.41,0.24,0.29$, and $0.36 \mathrm{~mm} \mathrm{day}^{-1}$ for Bushland, Clay Center, Davis, Gainesville, Phoenix, and Rockport. The RMSD value of $0.48 \mathrm{~mm} \mathrm{day}^{-1}$ for Clay Center was smaller than the RMSD value obtained from the HPRCC Penman equation $\left(0.56 \mathrm{~mm} \mathrm{day}^{-1}\right)$, which was originally calibrated for $\mathrm{Ne}$ braska conditions. The $1972 \mathrm{Kim}-\mathrm{Pen} \mathrm{ET}_{r}$ estimates were not significantly different from the ASCE-PM ET $r$ values at two locations; Davis and Phoenix. This was the only method that had nonsignificant $(P>0.05) \mathrm{ET}_{r}$ estimates as compared with the ASCE-PM estimates among all methods for the calendar year. It also had the highest $r^{2}$ values $(\geqslant 0.97)$ among all locations. Overall, its estimates were within $3 \%$ of the ASCE-PM estimates with the exception of Phoenix where the estimates were $6 \%$ lower than the ASCE-PM. Growing season estimates were very similar to those obtained for the calendar year, but the magnitude of the underestimations during the growing season increased from 3 to $8 \%$ at Davis and from 6 to $14 \%$ at Phoenix. Although the 1972 Kim-Pen method slightly over- or underestimated the ASCE-PM $\mathrm{ET}_{r}$ values, depending on location, it produced consistent estimates with less point scattering around the 1:1 line at both low and high $\mathrm{ET}_{r}$ rates throughout the year at all locations.

The 1982 Kim-Pen ET $r$ estimates agreed well with ASCE-PM $\mathrm{ET}_{r}$ values. The RMSD values were, however, higher than for the 1972 Kim-Pen at all locations, ranging from $0.54 \mathrm{~mm} \mathrm{day}^{-1}$ at Gainesville to $1.08 \mathrm{~mm} \mathrm{day}^{-1}$ at Bushland. Underestimations were within $3 \%$ of the ASCE-PM estimates at Bushland, Clay Center, Davis, and Rockport. The poorest estimates were at Gainesville and Phoenix, the two locations with the lowest wind speeds. The equation overestimated by 7 and $12 \%$ at Gainesville and Phoenix. The $\mathrm{ET}_{r}$ estimates during the growing season were considerably better than those in nongrowing seasons, especially at Bushland, Clay Center, Davis, and Rockport. The estimates during the growing season were not significantly different from the ASCE-PM estimates at Bushland and Davis (Table 5). Irmak et al. (2003) reported that the 1982 Kim-Pen was originally developed for the period of April through October with a polynomial wind function. The original wind function did not behave correctly during November through March and later was changed to the "normal equation" wind function (J. L. Wright, personal communication) as given by Jensen et al. (1990), which was the wind function used in this study. This wind function decreases to a base level for the winter months and accounts for the shorter daylength.

\section{Daily $K_{r}$ Values for Calendar Year and Growing Season}

\section{ASCE-PM $K_{r}$}

Although the ASCE-PM $K_{r}$ values showed some variation between the locations they were more consistent than other $K_{r}$ values (Fig. 1). Values determined with the ASCE-PM consistently exhibited an increasing trend from summer towards the winter months at all locations with maximum values in December and January. Although they differed in magnitude, the annual trend of $K_{r}$ values was similar for all locations. The $K_{r}$ values had less variation during the growing season (May-September) than the nongrowing (dormant) season. The largest day-to-day fluctuation during the growing season was observed at Rockport, followed by Clay Center and Gainesville. The largest $K_{r}$ values were observed at Bushland and Clay Center, two locations where hot, dry, and windy conditions cause high ET rates during the growing season. The large $K_{r}$ values $\geqslant 1.38$ during the summer months may reflect the advective, dry, and high wind environment typical of Bushland. These conditions are also often observed at Clay Center, especially during late July and early August where $\mathrm{ET}_{r}$ can exceed available energy $\left(R_{n}\right)$ reflecting advective conditions. The $K_{r}$ values ranged from 1.38 in July and August to a maximum of 1.55 and 1.56 in January and December, with calendar year and growing season averages of 1.46 and 1.40 (Table 6). The lowest $K_{r}$ values were in Gainesville, ranging from 1.11 in July to 1.30 in January. The $K_{r}$ values were always greater than 1.11 during the calendar year and growing season at all locations and the day-today variation of $K_{r}$ values was very small during the year. The average SD values among years were always less than 0.10 for the calendar year and less than 0.08 for the growing season. These results agree with those reported by Jensen et al. (1990) who observed $K_{r}$ values ranging from a low of 1.03 for calm, humid conditions to a high of 1.45 for extremely windy and dry conditions. However, the ASCE-PM $K_{r}$ values obtained in this study are somewhat higher than other $K_{r}$ values reported in the literature and are close to some of the $K_{r}$ values that are reported by other researchers. For example, in a lysimeter-measured alfalfa and grass ET study, Evett et al. (2000) reported that $\mathrm{ET}_{r}$ was 1.15 times higher than $\mathrm{ET}_{o}$ at Bushland, Tex., for the growing season. Doorenbos and Pruitt (1977) suggested a $K_{r}$ value of 1.15 for a dry climate with light to moderate wind. Erpenbeck (1981) obtained an average $K_{r}$ value of 1.21 using grass ET and pan evaporation data at Davis, Calif. Wright (1996) reported a seasonal $K_{r}$ value of 1.20 for Kimberly, Id.

It should be noted that the less variability in $K_{r}$ values does not necessarily mean higher accuracy and the term "variability" may also reflect the relative behavior of the methods when calculating the $K_{r}$ values. At first glance, the $K_{r}$ values developed using the ASCE-PM ET $r$ and $\mathrm{ET}_{o}$ values [Eq. (4)] might seem biased because two standardized forms of the Penman-Monteith equation 

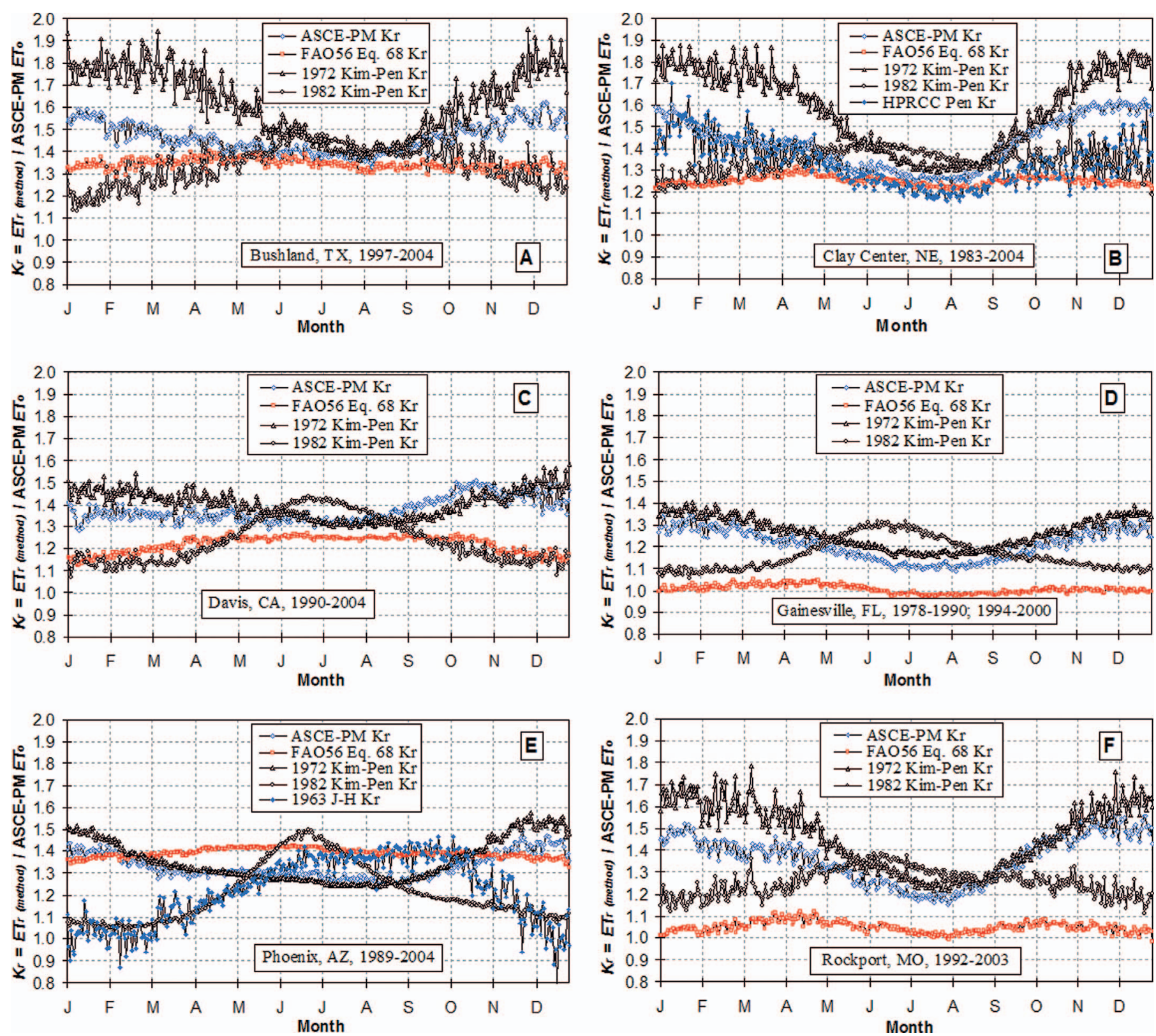

Fig. 1. (Color) Long-term average daily $\mathrm{ET}_{r}$ to $\mathrm{ET}_{o}$ ratios $\left(K_{r}\right.$ values) as function of date for each location for calendar year. Each $K_{r}$ value represents average of 8,22,15, 20,16, and 12 years of average values for Bushland, Clay Center, Davis, Gainesville, Phoenix, and Rockport. HPRCC Penman $K_{r}$ values were calculated only for Clay Center, and $1963 \mathrm{~J}-\mathrm{H} K_{r}$ values were calculated only for Phoenix.

were used to develop the $K_{r}$ values. However, these two equations represent two different reference surfaces and differ in respect to calibration parameters. Also, to somewhat minimize or normalize the "potential" biasness of the ASCE-PM $K_{r}$ method, the ASCE-PM ET ${ }_{o}$ was specifically used as the common denominator for all methods when calculating $K_{r}$. One may argue that the relative behavior of the ASCE-PM ET $\mathrm{T}_{\text {ref }}$ model for alfalfa and grass is less affected by climate variability than the relative behavior of two different models as used in the $K_{r}$ values in Eqs. (5)-(8). The relative behavior of the two differing ET models in the numerator as compared to the denominator of Eqs. (5)-(8) may be more pronounced as climate changes. It is not only the ASCE-PM method [Eq. (2)] that has the alfalfa surface in the numerator and grass surface in the denominator, but all Eqs. (4) -(8) have the alfalfa surface in the numerator and grass surface in the denominator. Although the values of the present $K_{r}$ analy- ses may show variation when the same reference ET model is used for alfalfa and grass [as in the case of Eq. (4)] versus when the same $\mathrm{ET}_{o}$ but different $\mathrm{ET}_{r}$ methods [in the case of Eqs. (5)-(8)] are used the effect of the relative behavior of the reference ET model on $K_{r}$ may be reduced. These two approaches also measures the robustness of the five different $\mathrm{ET}_{r}$ methods for estimating $\mathrm{ET}_{r}$ in different climates. Thus, in Eqs. (4)-(8), the consistency (less variability) of $K_{r}$ values will be somewhat a function of how consistently the $\mathrm{ET}_{r}$ values were estimated by the ASCE-PM, 1972 and 1982 K-P, HPRCC Penman, and 1963 J-H equations. Also, rather than it's potential biasness, a contrasting interpretation of the ASCE-PM method for determining $K_{r}$ values [Eq. (4)] is to acknowledge the advantage or the robustness of the method for developing the $K_{r}$ values. The ASCE-PM method has an advantage over other single $\mathrm{ET}_{r}$ equations that both $\mathrm{ET}_{r}$ and $\mathrm{ET}_{o}$ parameters (aerodynamic resistance and bulk surface resis- 
Table 6. Monthly Long-Term Average $\mathrm{ET}_{r}$ to $\mathrm{ET}_{o}$ Ratios ( $K_{r}$ Values) Calculated from Five Different $\mathrm{ET}_{r}$ Methods (ASCE-PM, FAO56 Eq. (68), 1963 J-H (for Phoenix only), HPRCC Penman (for Clay Center Only), 1972 Kim-Pen, and 1982 Kim-Pen) for Bushland, Tex., Clay Center, Neb., Davis, Calif., Gainesville, Fla., Phoenix, Ariz., and Rockport, Mo.) for Calendar Year and Growing Season

\begin{tabular}{|c|c|c|c|c|c|c|c|c|c|c|c|c|c|}
\hline \multirow[b]{2}{*}{ Month } & \multicolumn{6}{|c|}{ ASCE-PM $K_{r}$ and SD values } & \multicolumn{6}{|c|}{ FAO56 Eq. (68) $K_{r}$ and SD values } & \multirow{2}{*}{$\begin{array}{c}1963 \mathrm{~J}-\mathrm{H} K_{r} \\
\text { and } \\
\text { SD values } \\
\text { (Phoenix) }\end{array}$} \\
\hline & Bushland & C. Center & Davis & G.ville & Phoenix & Rockport & Bushland & C. Center & Davis & G.ville & Phoenix & Rockport & \\
\hline January & $1.55(0.09)$ & $1.55(0.11)$ & $1.35(0.17)$ & $1.30(0.13)$ & $1.40(0.10)$ & $1.47(0.12)$ & $1.33(0.05)$ & $1.23(0.06)$ & $1.15(0.06)$ & $1.01(0.05)$ & $1.37(0.04)$ & $1.03(0.05)$ & $1.03(0.26)$ \\
\hline February & $1.50(0.09)$ & $1.46(0.12)$ & $1.36(0.12)$ & $1.29(0.11)$ & $1.36(0.08)$ & $1.41(0.12)$ & $1.34(0.06)$ & $1.24(0.06)$ & $1.18(0.06)$ & $1.02(0.05)$ & $1.38(0.03)$ & $1.04(0.06)$ & $1.02(0.22)$ \\
\hline March & $1.46(0.10)$ & $1.42(0.11)$ & $1.35(0.09)$ & $1.25(0.09)$ & $1.31(0.07)$ & $1.39(0.10)$ & $1.35(0.06)$ & $1.27(0.06)$ & $1.21(0.05)$ & $1.03(0.05)$ & $1.39(0.03)$ & $1.08(0.06)$ & $1.11(0.20)$ \\
\hline April & $1.44(0.10)$ & $1.42(0.10)$ & $1.35(0.08)$ & $1.22(0.08)$ & $1.30(0.05)$ & $1.38(0.11)$ & $1.36(0.06)$ & $1.29(0.06)$ & $1.24(0.05)$ & $1.04(0.04)$ & $1.41(0.02)$ & $1.09(0.07)$ & $1.18(0.16)$ \\
\hline May & $1.42(0.08)$ & $1.33(0.10)$ & $1.33(0.07)$ & $1.18(0.07)$ & $1.30(0.01)$ & $1.30(0.09)$ & $1.37(0.05)$ & $1.26(0.06)$ & $1.24(0.04)$ & $1.02(0.04)$ & $1.42(0.00)$ & $1.06(0.05)$ & $1.26(0.03)$ \\
\hline June & $1.40(0.08)$ & $1.30(0.08)$ & $1.33(0.06)$ & $1.13(0.06)$ & $1.30(0.04)$ & $1.24(0.08)$ & $1.36(0.05)$ & $1.25(0.05)$ & $1.25(0.04)$ & $0.99(0.03)$ & $1.42(0.01)$ & $1.04(0.05)$ & $1.35(0.13)$ \\
\hline July & $38(0.06)$ & $1.27(0.07)$ & $1.32(0.04)$ & $1.11(0.06)$ & $1.28(0.05)$ & $1.19(0.06)$ & $1.34(0.04)$ & $1.23(0.04)$ & $1.25(0.02)$ & $0.98(0.03)$ & $1.40(0.02)$ & $1.02(0.04)$ & $1.37(0.12)$ \\
\hline August & $1.38(0.07)$ & $1.28(0.07)$ & $1.35(0.05)$ & $1.12(0.06)$ & $1.27(0.05)$ & $1.22(0.07)$ & $1.32(0.04)$ & $1.22(0.04)$ & $1.25(0.02)$ & $0.98(0.03)$ & $1.39(0.03)$ & $1.02(0.04)$ & $1.38(0.14)$ \\
\hline September & $1.44(0.07)$ & $1.41(0.09)$ & $1.41(0.06)$ & $1.16(0.09)$ & $1.29(0.06)$ & $1.33(0.09)$ & $1.33(0.04)$ & $1.25(0.05)$ & $1.25(0.03)$ & $0.99(0.04)$ & $1.39(0.03)$ & $1.05(0.04)$ & $1.40(0.17)$ \\
\hline October & $1.48(0.09)$ & $1.51(0.09)$ & $1.47(0.09)$ & $1.21(0.11)$ & $1.34(0.08)$ & $1.44(0.10)$ & $1.33(0.05)$ & $1.26(0.05)$ & $1.24(0.05)$ & $1.00(0.04)$ & $1.39(0.03)$ & $1.06(0.05)$ & $1.33(0.24)$ \\
\hline November & $1.53(0.12)$ & $1.58(0.09)$ & $1.45(0.13)$ & $1.26(0.12)$ & $1.41(0.08)$ & $1.49(0.12)$ & $1.33(0.06)$ & $1.25(0.05)$ & $1.19(0.06)$ & $1.00(0.04)$ & $1.38(0.03)$ & $1.05(0.05)$ & $1.20(0.30)$ \\
\hline December & $1.56(0.09)$ & $1.59(0.11)$ & $1.42(0.17)$ & $1.28(0.13)$ & $1.42(0.10)$ & $1.50(0.14)$ & $1.33(0.06)$ & $1.23(0.06)$ & $1.17(0.06)$ & $1.00(0.05)$ & $1.36(0.04)$ & $1.03(C$ & (0.29) \\
\hline C.Y. & $1.46(0.09)$ & $1.43(0.10)$ & $1.37(0.09)$ & $1.21(0.09)$ & $1.33(0.07)$ & $1.36(0.10)$ & $1.34(0.05)$ & $1.25(0.05)$ & $1.22(0.05)$ & $1.01(0.04)$ & $1.39(0.03)$ & $1.05(0.05)$ & $1.22(0.19)$ \\
\hline \multirow[t]{3}{*}{ G.S. } & $1.40(0.07)$ & $1.35(0.08)$ & $1.35(0.06)$ & $1.14(0.07)$ & $1.29(0.04)$ & $1.25(0.08)$ & $1.34(0.05)$ & $1.25(0.05)$ & $1.25(0.03)$ & $0.99(0.03)$ & $1.40(0.02)$ & $1.04(0.04)$ & $1.35(0.12)$ \\
\hline & \multicolumn{6}{|c|}{$1972 \mathrm{Kim}-\mathrm{Pen} K_{r}$ and SD values } & \multicolumn{6}{|c|}{$1982 \mathrm{Kim}-\mathrm{Pen} K_{r}$ and SD values } & \multirow{2}{*}{$\begin{array}{c}\text { HPRCC } K_{r} \\
\text { and } \\
\text { SD values } \\
\text { (C. Center) }\end{array}$} \\
\hline & Bushland & C. Center & Davis & G.ville & Phoenix & Rockport & Bushland & C. Center & Davis & G.ville & Phoenix & Rockport & \\
\hline January & $1.78(0.17)$ & $1.79(0.24)$ & $1.46(0.13)$ & $1.36(0.09)$ & $1.48(0.11)$ & $1.65(0.21)$ & $1.20(0.14)$ & $1.25(0.22)$ & $1.14(0.11)$ & $1.08(0.06)$ & $1.07(0.06)$ & $1.18(0.14)$ & $1.50(0.26)$ \\
\hline Febuary & $1.79(0.19)$ & $1.76(0.27)$ & $1.46(0.13)$ & $1.35(0.09)$ & $1.40(0.06)$ & $1.61(0.18)$ & $1.25(0.14)$ & $1.31(0.24)$ & $1.13(0.09)$ & $1.09(0.06)$ & $1.06(0.04)$ & & $.22)$ \\
\hline March & $1.76(0.19)$ & $1.72(0.31)$ & $1.43(0.11)$ & $1.31(0.08)$ & $1.34(0.04)$ & $1.59(0.19)$ & $1.29(0.16)$ & $1.33(0.27)$ & $1.15(0.07)$ & $1.11(0.05)$ & $1.09(0.03)$ & $1.23(0.13)$ & $1.41(0.20)$ \\
\hline April & $1.68(0.17)$ & $1.66(0.23)$ & $1.43(0.11)$ & $1.27(0.06)$ & $1.31(0.03)$ & $1.53(0.17)$ & $1.33(0.14)$ & $1.35(0.19)$ & $1.21(0.06)$ & $1.16(0.04)$ & $1.17(0.04)$ & $1.27(0.12)$ & $1.37(0.16)$ \\
\hline May & $1.56(0.13)$ & $1.51(0.17)$ & $1.38(0.09)$ & $1.23(0.05)$ & $1.29(0.01)$ & $1.39(0.10)$ & $1.38(0.08)$ & $1.39(0.11)$ & $1.32(0.06)$ & $1.25(0.05)$ & $1.32(0.05)$ & $1.32(0.05)$ & $1.29(0.03)$ \\
\hline June & $1.49(0.09)$ & $1.39(0.10)$ & $1.35(0.07)$ & $1.19(0.04)$ & $1.27(0.02)$ & $1.31(0.08)$ & $1.46(0.05)$ & $1.42(0.07)$ & $1.41(0.04)$ & $1.29(0.05)$ & $1.46(0.06)$ & $1.36(0.05)$ & $1.24(0.13)$ \\
\hline July & $1.41(0.06)$ & $1.32(0.06)$ & $1.32(0.05)$ & $1.17(0.04)$ & $1.25(0.02)$ & $1.25(0.06)$ & $1.45(0.04)$ & $1.38(0.05)$ & $1.40(0.03)$ & $1.27(0.06)$ & $1.41(0.07)$ & $1.31(0.05)$ & $1.20(0.12)$ \\
\hline August & $1.41(0.07)$ & $1.33(0.06)$ & $1.32(0.05)$ & $1.18(0.04)$ & $1.25(0.02)$ & $1.26(0.05)$ & $1.40(0.06)$ & $1.33(0.06)$ & $1.34(0.05)$ & $1.20(0.05)$ & $1.29(0.05)$ & $1.27(0.05)$ & $1.20(0.14)$ \\
\hline September & $1.49(0.10)$ & $1.44(0.13)$ & $1.34(0.05)$ & $1.21(0.06)$ & $1.29(0.04)$ & $1.35(0.07)$ & $1.40(0.09)$ & $1.35(0.12)$ & $1.25(0.06)$ & $1.16(0.04)$ & $1.20(0.03)$ & $1.27(0.06)$ & $1.28(0.17)$ \\
\hline October & $1.60(0.14)$ & $1.59(0.22)$ & $1.41(0.10)$ & $1.26(0.06)$ & $1.38(0.06)$ & $1.45(0.10)$ & $1.38(0.13)$ & $1.37(0.20)$ & $1.20(0.08)$ & $1.14(0.03)$ & $1.17(0.03)$ & $1.25(0.08)$ & $1.30(0.24)$ \\
\hline November & $1.69(0.17)$ & $1.76(0.31)$ & $1.45(0.12)$ & $1.31(0.07)$ & $1.49(0.09)$ & $1.57(0.14)$ & $1.30(0.14)$ & $1.38(0.31)$ & $1.15(0.08)$ & $1.11(0.03)$ & $1.14(0.05)$ & $1.23(0.13)$ & $1.33(0.30)$ \\
\hline December & $1.79(0.18)$ & $1.80(0.25)$ & $1.50(0.14)$ & $1.35(0.08)$ & $1.53(0.11)$ & $1.62(0.16)$ & $1.28(0.15)$ & $1.30(0.26)$ & $1.15(0.11)$ & $1.10(0.05)$ & $1.11(0.06)$ & $1.19(0.13)$ & $1.40(0.29)$ \\
\hline C.Y. & $1.62(0.14)$ & $1.59(0.20)$ & $1.40(0.10)$ & $1.27(0.06)$ & $1.36(0.05)$ & $1.46(0.13)$ & $1.34(0.11)$ & $1.35(0.17)$ & $1.24(0.07)$ & $1.16(0.05)$ & $1.21(0.05)$ & $1.26(0.09)$ & $1.33(0.19)$ \\
\hline G.S. & $1.47(0.09)$ & $1.43(0.12)$ & $1.34(0.06)$ & $1.19(0.05)$ & $1.27(0.02)$ & $1.31(0.07)$ & $1.42(0.06)$ & $1.37(0.10)$ & $1.34(0.5)$ & $1.23(0.05)$ & $1.33(0.05)$ & $1.31(0.05)$ & $1.25(0.12)$ \\
\hline
\end{tabular}

Note: Values in parenthesis indicate standard deviations (SD). Long-term average SD values were calculated for each ET $r$ method as the SD values between the long-term average $K_{r}$ values and individual years' $K_{r}$ values for each year and averaged for long term. Each $K_{r}$ and SD value represents an average of 8, 22, 15, 20, 16, and 12 years for Bushland, Clay Center, Davis, Gainesville, Phoenix, and Rockport. C.Y.=calendar year, G.S.=growing season (May-September).

tance) were combined into a single equation having different calibration parameters and time step coefficients. Thus, the ASCE-PM $K_{r}$ method might provide a more conclusive indication and/or information on the interpretation of the true variability in $K_{r}$ values between the locations and between the seasons for the same location, and transferability of the $K_{r}$ values from one location to another.

\section{FA056 $K_{r}$}

The $K_{r}$ values obtained with the FAO56 method [Eq. (1)] fluctuated in a substantially narrower range throughout the calendar year and growing season than any other method with nonconsistent values among locations (Fig. 1). For example, Bushland, Davis, and Phoenix had maximum $K_{r}$ values during the growing season and the values steadily decreased towards the winter months. However, at Clay Center, Gainesville, and Rockport, a considerably different trend was observed, with the largest values during spring and fall, and minimum values during the growing season. This might be due to differences in the seasonal trends of $\mathrm{RH}_{\text {min }}$ and $U_{2}$ at different locations. Unlike the ASCE-PM, the
FAO56 procedure had the largest $K_{r}$ values at Phoenix, followed by Bushland. The values ranged from 1.36 and 1.37 in December and January to 1.42 in May and June. The $K_{r}$ values were smaller at humid locations as compared with the arid and semiarid locations. The smallest $K_{r}$ values were obtained at Gainesville. Some of the $K_{r}$ values produced by the FAO-56 method seem unusual and possibly unrealistic. For reasons stated earlier related to alfalfa and grass reference surfaces, one would expect $\mathrm{ET}_{r}>\mathrm{ET}_{o}$ for any climate. However, the $K_{r}$ values obtained with this method averaged 1.01 for the calendar year and 0.99 for the growing season, indicating that $\mathrm{ET}_{r}<\mathrm{ET}_{o}$, which seems unusual. At Rockport, $K_{r}$ values also seem low, averaging 1.05 for the calendar year, and 1.04 for the growing season.

The inconsistent $K_{r}$ values among locations obtained with this method might be due to the magnitude of the weather variables $\left(\mathrm{RH}_{\min }\right.$ and $\left.U_{2}\right)$ used to develop and calibrate Eq. (1). In this equation, the base values of $45 \%$ and $2 \mathrm{~m} \mathrm{~s}^{-1}$ for $\mathrm{RH}_{\text {min }}$ and $U_{2}$, respectively, seem too large and may not work for climatic conditions that differ significantly from those for which the equation 

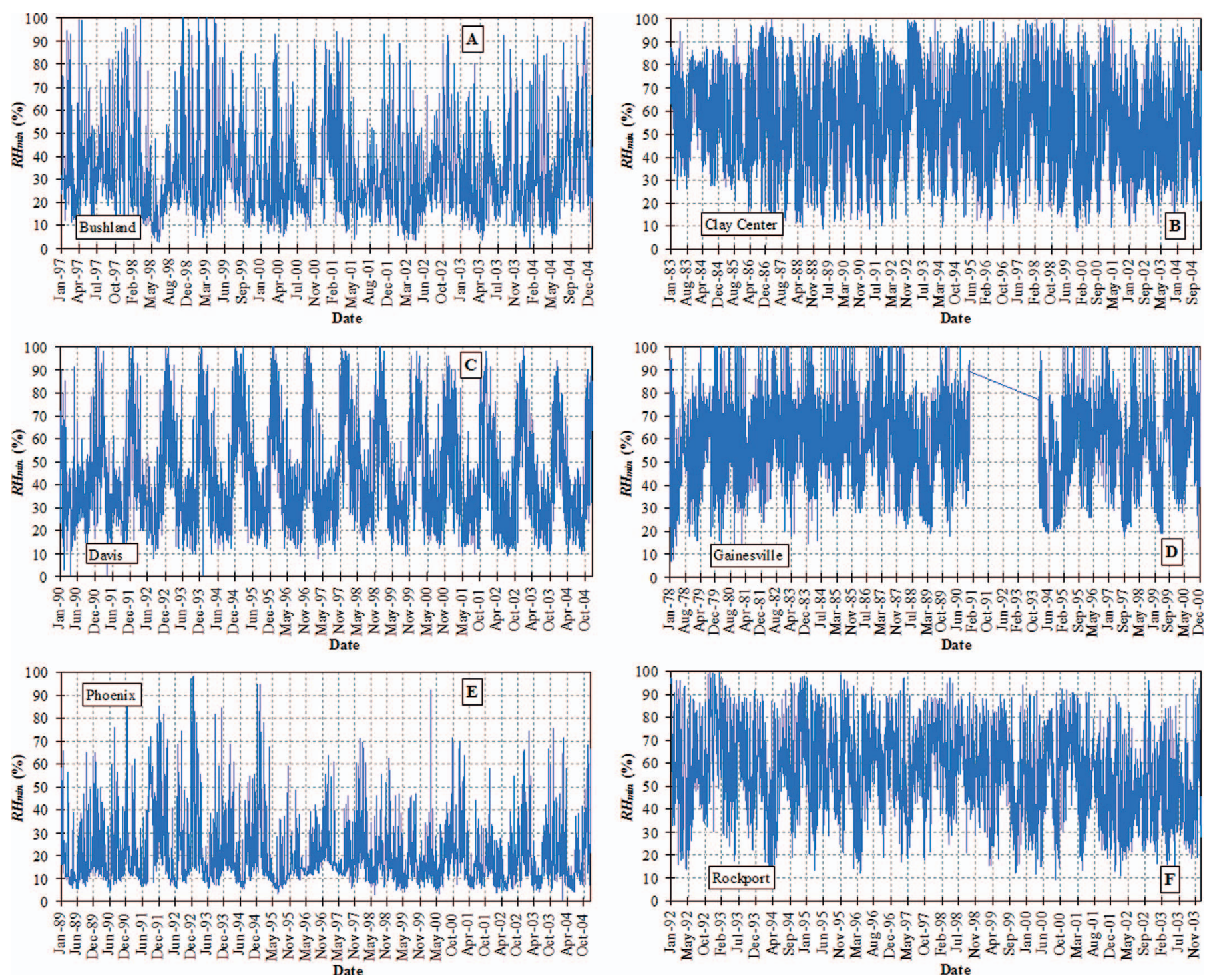

Fig. 2. (Color) Long-term daily $\mathrm{RH}_{\min }$ values at each study site. These datasets are provided for comparison with base values of $\mathrm{RH}_{\text {min }}$ that were used in FAO56 $K_{r}$ calculation procedure [Eq. (1) of this study].

was developed. To further test this hypothesis, daily $\mathrm{RH}_{\min }$ and $U_{2}$ values for each study site were graphed in Figs. 2 and 3 to assess the long-term magnitude and trend and possible effects of the base values of $\mathrm{RH}_{\text {min }}$ and $U_{2}$ on the performance of the FAO56 $K_{r}$ procedure in different climates. Usually, at Bushland and Davis $\mathrm{RH}_{\text {min }}$ is less than $45 \%$, especially during the growing season (Fig. 2). Fig. 3 indicates that $U_{2}$ at Bushland is rarely below $2 \mathrm{~m} \mathrm{~s}^{-1}$, whereas at Gainesville and Phoenix it rarely exceeds $2 \mathrm{~m} \mathrm{~s}^{-1}$. At Rockport and Davis, $U_{2}$ is less than $2 \mathrm{~m} \mathrm{~s}^{-1}$ approximately $40 \%$ of the time. At Phoenix, $\mathrm{RH}_{\min }$ is less than $45 \%$ about $90 \%$ of the time. Therefore, for most of the time at this location the $\mathrm{RH}_{\text {min }}-45$ and $U_{2}-2$ terms in Eq. (1) would be either zero or negative and $K_{r}$ would only be a function of the coefficient $C$. Coefficient $C$ alone cannot provide accurate or realistic $K_{r}$ values. These findings suggest that the local calibration of Eq. (1) for $\mathrm{RH}_{\text {min }}$ and $U_{2}$ for local climate will enhance its capability to provide more realistic and consistent $K_{r}$ values as compared to the ASCE-PM $K_{r}$ values.

\section{2 and 1982 Kim-Pen $K_{r}$}

The $K_{r}$ values from two Kimberly forms of Penman equations showed opposite trends. The 1972 Kim-Pen equation resulted in the largest $K_{r}$ values during the dormant (winter) season, and decreased gradually towards the growing season (Fig. 1). The 1982 Kim-Pen produced the largest $K_{r}$ values during the growing season and decreased gradually towards winter. The opposite trend in $K_{r}$ values between the two equations might be due to a combination of differences in the wind functions used and the performance in estimating $\mathrm{ET}_{r}$ relative to the ASCE-PM ET $r$. Both Kim-Pen equations always resulted in $K_{r}>1.0$ with the lowest values obtained at the most humid location, Gainesville. The growing season average $K_{r}$ values were similar for both methods. The 1972 Kim-Pen method resulted in the closest $K_{r}$ values compared with the ASCE-PM method at all locations. The 1972 KimPen values were lowest during the growing season at Gainesville, and unlike other locations, this is the time of the year when the highest RH occurs. Jensen et al. (1990) stated that as humidity 

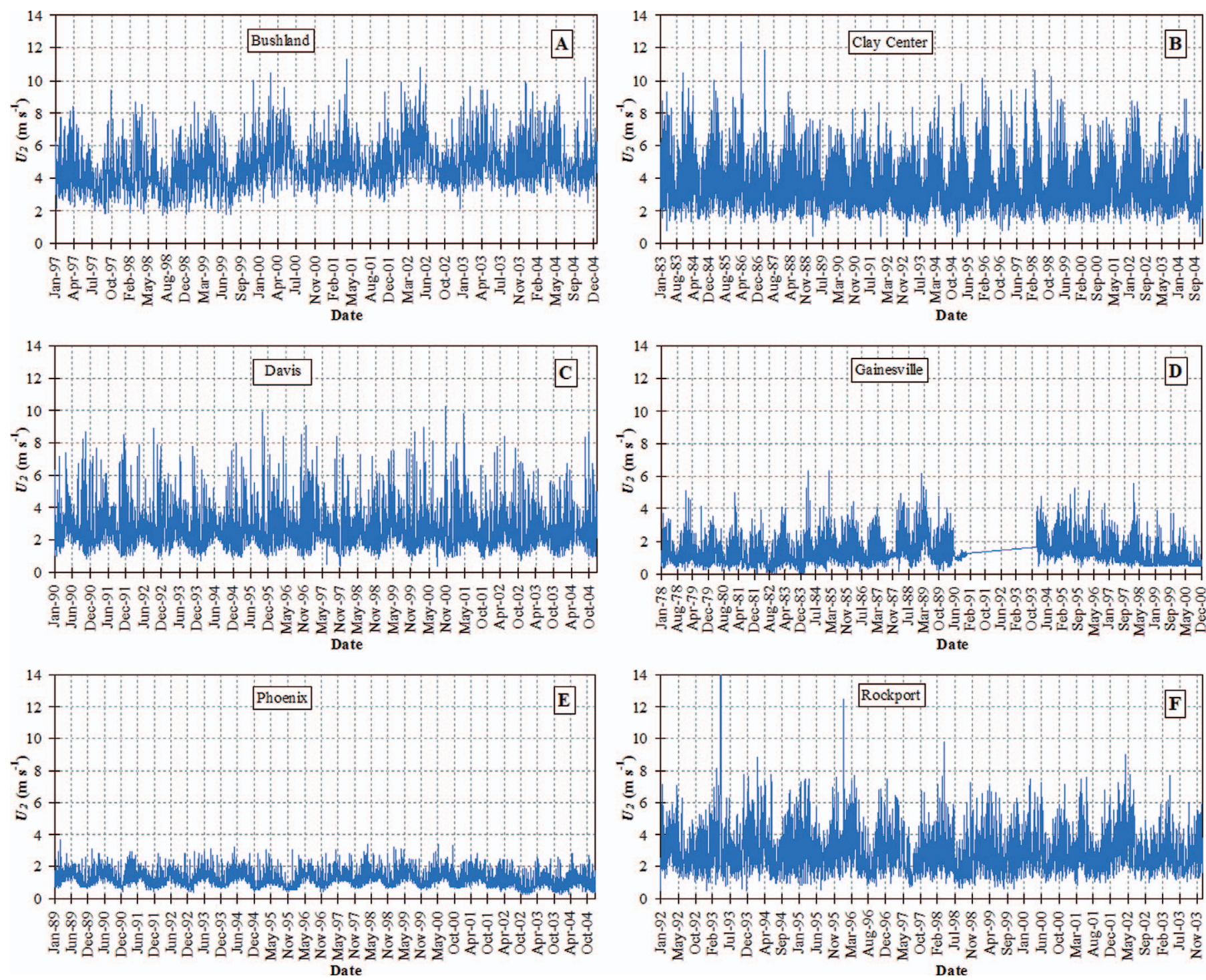

Fig. 3. (Color) Long-term daily $U_{2}$ values at each study site. These datasets are provided for comparison with base values of $U_{2}$ that were used in FAO56 $K_{r}$ calculation procedure [Eq. (1) of this study].

increases the $K_{r}$ values should decrease. The 1972 Kim-Pen $K_{r}$ values were largest at Bushland followed by Clay Center, and were similar to the ASCE-PM values. The average values were as high as 1.79 and 1.78 in December and January at Bushland and 1.80 in the same months at Clay Center. In general, the 1972 Kim-Pen values had larger day-to-day fluctuations than other methods at all locations, especially during the dormant season, with less variation during the middle of the growing season.

\section{$1963 \mathrm{~J}-\mathrm{H}$ and HPRCC $\mathrm{K}_{r}$}

The $1963 \mathrm{~J}-\mathrm{H} K_{r}$ values were calculated only for Phoenix due to the very poor $\mathrm{ET}_{r}$ estimates at other locations (Table 5). The $K_{r}$ values were lowest during the nongrowing season with highest values observed from May through early October. The values were less than 1.0 during the winter months. Very low ratios $(<1.0)$ are due to a combination of low estimates of $\mathrm{ET}_{r}$ by this method, and potentially high estimates of $\mathrm{ET}_{o}$ by the ASCE-PM method during the nongrowing season. The calendar year and growing season monthly average values were 1.22 and 1.35 with year-to-year variation of 0.19 and 0.12 (Table 6). The HPRCC
Penman $K_{r}$ values were developed only for Clay Center. The $K_{r}$ values had similar magnitudes and followed trends similar to the ASCE-PM values from mid January through late September, but deviated substantially from October through January (Fig. 1). This deviation was due to underestimation of $\mathrm{ET}_{r}$ by this method

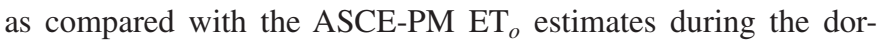
mant season. The $K_{r}$ values were 6-7\% lower than the ASCE-PM $K_{r}$ values from June through September. Values ranged from 1.20 in July and August to 1.50 in January, averaging 1.33 and 1.25 for the calendar year and growing season, respectively. The $K_{r}$ values had the same year-to-year variations $(0.19$ and 0.12 for the same periods) as the $1963 \mathrm{~J}-\mathrm{H}$ method.

The aforementioned finding indicated that the $K_{r}$ values presented considerable variability among locations and between the seasons within the same location with the ASCE-PM $K_{r}$ values exhibiting the least variability. In general, the variability during the growing season was less than during the calendar year for most of the methods. However, for both periods, there was more than $25 \%$ variability in $K_{r}$ values among locations to justify the need for developing $K_{r}$ values for specific climates. For example, 
the calendar year average values for the ASCE-PM were 1.46, $1.43,1.37,1.21,1.33$, and 1.36 for Bushland, Clay Center, Davis, Gainesville, Phoenix, and Rockport. While the values were similar for Bushland and Clay Center, they were about 7, 17, 8, and $6 \%$ higher than the values for Davis, Gainesville, Phoenix, and Rockport. Using one $K_{r}$ value developed for a local climate using one method in other climates could result up to a $20-25 \%$ difference in estimating ET and $K_{c}$. The FAO56 procedure resulted in the highest variability among locations for all methods. The $K_{r}$ values for Gainesville and Rockport calculated using the FAO56 procedure were 25 and $22 \%$ lower than those for Bushland for the calendar year, and 26 and $22 \%$ lower for the growing season.

\section{Nongrowing (Dormant) Season $E T_{\text {ref }}$ and $K_{r}$}

Although, in many cases, the emphasis is on the growing season ET and $K_{r}$ values, the dormant season $K_{r}$ and $\mathrm{ET}_{\text {ref }}$ values are of interest because they can be useful tools to asses the dormant season evaporative demand of the atmosphere. As shown earlier, some of the methods produced some "potentially unrealistically" high (e.g., 1.78, 1.80) $K_{r}$ values during the dormant periods. This is, in part, due to the unrealistic $\mathrm{ET}_{\text {ref }}$ estimations of the methods, including ASCE-PM ET $r$ and $\mathrm{ET}_{o}$ estimates. Allen et al. (1998) defined the dormant season as periods during which no agricultural crop has been planted. In temperate regions, the dormant season may include periods of frost and continuously frozen conditions. Obviously the length of the dormant season varies among locations and it may be only 1 month or two at Gainesville or as long as 6-7 months at other locations. The possible unrealistic estimates of the combination-based $\mathrm{ET}_{\text {ref }}$ equations have been acknowledged in the past. ASCE-EWRI (2005) stated that the ET from nonactive vegetation during dormant periods is generally less than $\mathrm{ET}_{\text {ref }}$ because of the substantially increased surface resistance $\left(r_{s}\right)$. While it is recognized that the $\mathrm{ET}_{\text {ref }}$ equations do not completely represent measurable quantities of evaporative demand of the air during dormant periods, the standardized ASCE-PM equation can still be useful as an evaporative index. The possible reasons for unrealistic $\mathrm{ET}_{\text {ref }}$ estimates by the combination methods can be a function of a combination of factors. In addition to the increased bulk surface resistance, $r_{s}$, Jensen (2006, personal communication) suggested that the following conditions contribute to unrealistic $\mathrm{ET}_{\text {ref }}$ estimates during dormant periods: (1) the change in the amount of daytime hours to nighttime hours; (2) the greater emphasis of the aerodynamic component of the combination equation relative to the radiation component during periods with lower temperatures; and (3) unrealistic values of $r_{s}$ at low temperatures. To address the greater effect of the aerodynamic component relative to the radiation component during periods with lower temperatures, use of sum-of-hourly calculations may reduce the effect somewhat. The impacts of using $24 \mathrm{~h}$ average weather data to predict ET that occurs mainly over approximately an $8 \mathrm{~h}$ period also introduces errors during winter. Irmak et al. (2005) suggested that there is a benefit and potential improvement in accuracy when the standardized ASCE-PM procedure is applied hourly instead of daily for $\mathrm{ET}_{\text {ref }}$ estimates, especially during the dormant seasons. The hourly application helps to account for impacts of abrupt changes in atmospheric conditions on $\mathrm{ET}_{\text {ref }}$ estimation.

Jensen (2006, personal communication) further stated that the unrealistic values of $r_{s}$ at low temperatures could affect $\mathrm{ET}_{r}$ more than $\mathrm{ET}_{o}$. Perhaps a rational approach for $\mathrm{ET}_{r}$ would be to arbitrarily increase the $r_{s}$ when temperatures fall below values that can sustain or mimic actively growing vegetation. This could be based on alfalfa growth characteristics if the $r_{s}$ data are available during dormant periods. Also, one could assume that the vegetation height (effective roughness) decreases either suddenly or gradually to some low base value such as $0.05 \mathrm{~m}$ as cold temperatures occur. The $r_{s}$ would be decreased following rains that cause wet surface conditions. Furthermore, the calculation of $R_{n}$ during the growing season assumes an albedo $(\alpha)$ value of 0.23 for a green vegetation surface, which is not realistic during dormant periods. Experimental knowledge and adequate procedures to estimate soil heat flux (especially for hourly calculations) during freezing conditions are lacking. Thus, the "standardized" reference surface conditions now used in the "standardized" ASCE-PM equation are not met during dormant periods, resulting in potentially unrealistic estimates of $K_{r}$ values. The effect of the potentially unrealistically high estimates of $K_{r}$ values on $\mathrm{ET}_{\text {ref }}$ estimates during the dormant period rather than growing season should be lower than one would expect due to low $\mathrm{ET}_{r}$ and $\mathrm{ET}_{o}$ values during the dormant periods. Nevertheless, information is lacking on the "true" performance of the $\mathrm{ET}_{\text {ref }}$ estimates and "true" values of the $K_{r}$ as determined by the combination equations, including the ASCE-PM estimates during the dormant periods. The analyses and comparisons of the dormant period ET by combination methods against measured data and developing robust methodologies to quantify dormant season ET and $K_{r}$ are needed.

\section{Conclusions}

The $K_{r}$ coefficients that can enable conversions from $\mathrm{ET}_{r}$ to $\mathrm{ET}_{o}$, or vice versa, were developed for six locations differing in climatic characteristics. The first approach of developing $K_{r}$ values was ASCE-PM ET $r$ to $\mathrm{ET}_{o}$ ratios, and the second was the equation proposed in FAO56 as a function of $\mathrm{RH}_{\text {min }}, U_{2}$, and a coefficient. The variability in $K_{r}$ values among locations was large, suggesting the need to develop $K_{r}$ values for a local region. For example, the $K_{r}$ values developed with the ASCE-PM method in July were $1.38,1.27,1.32,1.11,1.28$, and 1.19, for Bushland, Clay Center, Davis, Gainesville, Phoenix, and Rockport, respectively. In general, the variation in growing season $K_{r}$ values was less than for the calendar year. The magnitude of variation among locations was less for the ASCE-PM $K_{r}$ values than for other methods at all locations. The variability among locations was larger for the FAO56 method, especially for areas with low relative humidity and high wind speeds. Our findings suggest that the local calibration of this approach for minimum relative humidity and wind speed for local climate will enhance its capability to provide more realistic and consistent $K_{r}$ values as compared to the ASCE-PM $K_{r}$ values. In general, year-to-year variability in $K_{r}$ for the same location was low. The differences also varied substantially among locations for a given method, with the difference being lower when the ASCE-PM $K_{r}$ values were used. Some of the methods produced high and "potentially" unrealistic $K_{r}$ values during the dormant periods. One can normally expect these very high $K_{r}$ values under conditions of very strong wind and very large VPD. However, the VPD during winter is not extremely large in some of the locations studied. Potentially unrealistic $K_{r}$ values might be due to inaccuracies in the $\mathrm{ET}_{\text {ref }}$ calculations during winter months. Because simultaneous and direct measurements of the $\mathrm{ET}_{r}$ and $\mathrm{ET}_{o}$ values rarely exist, it appears that the approach of $\mathrm{ET}_{r}$ to $\mathrm{ET}_{o}$ ratios calculated with the ASCE-PM method is currently the best approach available to derive $K_{r}$ values for locations where these measurements are not available. The 
$K_{r}$ values developed in this study can be useful for making conversions from $\mathrm{ET}_{r}$ to $\mathrm{ET}_{o}$, or vice versa, to enable using crop coefficients developed for one reference surface with the other to determine actual crop water use for locations, with similar climatic characteristics of this study, when locally measured $K_{r}$ values are not available.

\section{Acknowledgments}

A contribution of the University of Nebraska-Lincoln Agricultural Research Division, Lincoln, Nebraska, Journal Series No. 15160. The mention of trade names or commercial products is solely for the information of the reader and does not constitute an endorsement or recommendation for use by the University of NebraskaLincoln or the USDA Agricultural Research Service.

\section{References}

Allen, R. G. (1996). "Assessing integrity of weather data for reference evapotranspiration estimation.” J. Irrig. Drain. Eng., 122(2), 97-106.

Allen, R. G., Pereira, L. S., Raes, D., and Smith, M. (1998). "Crop evapotranspiration. Guidelines for computing crop water requirements." FAO Irrig., and Drain. Paper No. 56, Rome, Italy.

Allen, R. G., Smith, M., Perrier, A., and Pereira, L. S. (1994). "An update for the definition of reference evapotranspiration." ICID Bulletin, 43(2), 1-34.

ASCE Environmental and Water Resources Institute (EWRI). (2005). "The ASCE standardized reference evapotranspiration equation." Standardization of Reference Evapotranspiration Task Committee Final Rep., R. G. Allen, I. A. Walter, R. L. Elliot, T. A. Howell, D. Itenfisu, M. E. Jensen, and R. L. Snyder, eds., ASCE, Reston, Va.

AZMET. (2006). Arizona meteorological network, 〈http://ag.arizona.edu/ azmet) (November 2006).

Burman, R. D., and Pochop, L. O. (1994). "Evaporation, evapotranspiration and climate data." Developments in atmospheric science, Vol. 22, Elseiver Science, Amsterdam, The Netherlands.

CIMIS. (2006). "California irrigation management information system." $\langle$ http://www.cimis.water.ca.gov〉 (November 2006).

Doorenbos, J., and Pruitt, W. O. (1977). "Guidelines for prediction of crop water requirements." FAO Irrig., and Drain. Paper No. 24, revised, Rome, Italy.

Droogers, P., and Allen, R. G. (2002). "Estimating reference evapotranspiration under inaccurate data conditions." Irrig. Drain. Syst., 16, 33-45.

Erpenbeck, J. M. (1981). "A methodology to estimate crop water requirements in Washington State.” MS thesis, Washington State Univ., Pullman, Wash.

Evett, S. R., Howell, T. A., Todd, R. W., Schneider, A. D., and Tolk, J. A. (2000). "Alfalfa reference ET measurement and prediction." Proc. 4th Decennial National Irrig. Symp., ASAE, St. Joseph, Mich., 266-272.

HPRCC. (2006). High Plains Regional Climate Center, 〈http:// www.hprcc.unl.edu (November 2006).

Hubbard, K. G. (1992). "Climatic factors that limit daily evapotranspiration in sorghum." Climate Research, 2, 73-80.

Irmak, S., Howell, T. A., Allen, R. G., Payero, J. O., and Martin, D. L. (2005). "Standardized ASCE-Penman-Monteith: Impact of sum-ofhourly vs. 24-h timestep computations at reference weather station sites." Transactions of the ASABE, 48(3), 1063-1077.

Irmak, S., Irmak, A., Allen, R. G., and Jones, J. W. (2003). "Solar and net radiation-based equations to estimate reference evapotranspiration in humid climates." J. Irrig. Drain. Eng., 129(5), 336-347.

Itenfisu, D., Elliot, R. L., Allen, R. G., and Walter, I. A. (2003). "Comparison of reference evapotranspiration calculations as part of the ASCE standardization effort." J. Irrig. Drain. Eng., 129(6), 440-448.

Jensen, M. E. (1969). "Scheduling irrigations using computers." Arab Wat. World, 24(8), 193-195.

Jensen, M. E., Burman, R. D., and Allen, R. G. (1990). "Evapotranspiration and irrigation water requirements." ASCE Manuals and Reports on Engineering Practices No. 70, ASCE, New York.

Jensen, M. E., and Haise, H. R. (1963). "Estimating evapotranspiration from solar radiation." J. Irrig. and Drain. Div., 89, 15-41.

Kincaid, D. C., and Heerman, D. F. (1974). "Scheduling irrigations using a programmable calculator." USDA-ARS Rep. No. ARS-NC-12, USDA, Phoenix.

Penman, H. L. (1948). "Natural evaporation from open water, bare soil and grass." Proc. R. Soc. London, Ser. A, 193, 120-146.

Snyder, R. L., and Pruitt, W. O. (1985). "Estimating reference evapotranspiration with hourly data." California Irrigation Management Information System Final Rep., Land, Air and Water Resources Paper No. 10013-A, Chap. VII, Vol. 1, Univ. of California, Davis, Calif.

Snyder, R. L., and Pruitt, W. O. (1992). "Evapotranspiration data management in California." Proc. ASCE Water Forum '92, Irrig. and Drain. Session, ASCE, New York, 128-133.

Temesgen, B., Allen, R. G., and Jensen, D. T. (1999). "Adjusting temperature parameters to reflect well-watered conditions." J. Irrig. Drain. Eng., 125(1), 26-33.

Walter, I. A., et al. (2001). "The ASCE standardized reference evapotranspiration equation." Standardization of Reference Evapotranspiration Task Committee Rep., Environmental and Water Resources Institute (EWRI) of ASCE.

Wright, J. L. (1982). "New evapotranspiration crop coefficients.” J. Irrig. and Drain. Div., 108(IR2), 57-74.

Wright, J. L. (1996). "Derivation of alfalfa and grass reference evapotranspiration." Evapotranspiration and Irrigation Scheduling: Proc., International Conf., Irrigation Association and International Committee on Irrigation and Drainage, C. R. Camp, E. J. Sadler, and R. E. Yoder, eds., American Society of Agricultural Engineers, St. Joseph, Mich.

Wright, J. L., Allen, R. G., and Howell, T. A. (2000). "Conversion between evapotranspiration references and methods." Proc. 4th Decennial National Irrigation Symp., American Society of Agricultural Engineers, St. Joseph, Mich.

Wright, J. L., and Jensen, M. E. (1972). "Peak water requirements of crops in Southern Idaho.” J. Irrig. and Drain. Div., 96(IR1), 193-201. 